\title{
Development and validation of a framework for the assessment of school curricula on the presence of evolutionary concepts (FACE)
}

\author{
Xana Sá-Pinto ${ }^{1}$, Giulia Realdon², Gregor Torkar ${ }^{3}$ Bruno Sousa ${ }^{4}$, Martha Georgiou ${ }^{5}$, Alex Jeffries ${ }^{6}$, \\ Konstantinos Korfiatis ${ }^{7}$, Silvia Paolucci ${ }^{8}$, Patrícia Pessoa ${ }^{1}$, Joana Rocha ${ }^{9}$, Panagiotis K. Stasinakis ${ }^{10}$, \\ Bento Cavadas ${ }^{11,12}$, Angelica Crottini ${ }^{13}$, Tanja Gnidovec ${ }^{3}$, Teresa Nogueira ${ }^{14,15}$, Penelope Papadopoulou ${ }^{16}$, \\ Costanza Piccoli ${ }^{13}$, Johan Barstad ${ }^{17}$, Heloise D. Dufour ${ }^{18}$, Milena Pejchinovska ${ }^{19}$, Alma Pobric ${ }^{20}$, \\ Dragana Cvetković ${ }^{21}$ and Evangelia Mavrikaki ${ }^{22^{*}}$ (i)
}

\begin{abstract}
Evolution is a key concept of biology, fundamental to understand the world and address important societal problems, but research studies show that it is still not widely understood and accepted. Several factors are known to influence evolution acceptance and understanding, but little information is available regarding the impacts of the curriculum on these aspects. Very few curricula have been examined to assess the coverage of biological evolution. The available studies do not allow comparative analyses, due to the different methodologies employed by the authors. However, such an analysis would be useful for research purposes and for the development of appropriate educational policies to address the problem of a lack of evolution acceptance in some countries. In this paper we describe the steps through which we developed a valid and reliable instrument for curricula analysis known as FACE: "Framework to Assess the Coverage of biological Evolution by school curricula."This framework was developed based on the "Understanding Evolution Conceptual Framework" (UECF). After an initial pilot study, our framework was reformulated based on identified issues and experts' opinions. To generate validity and reliability evidence in support of the framework, it was applied to four European countries' curricula. For each country, a team of a minimum of two national and two foreign coders worked independently to assess the curriculum using this framework for content analysis. Reliability evidence was estimated using Krippendorf's alpha and resulted in appropriate values for coding the examined curricula. Some issues that coders faced during the analysis were discussed and, to ensure better reliability for future researchers, additional guidelines and one extra category were included in the framework. The final version of the framework includes six categories and 34 subcategories. FACE is a useful tool for the analysis and the comparison of curricula and school textbooks regarding the coverage of evolution, and such results can guide curricula development.
\end{abstract}

Keywords: Curricula analysis, Evolution education, Content analysis, Learning goals

*Correspondence: emavrikaki@primedu.uoa.gr

22 Faculty of Primary Education, National and Kapodistrian University of Athens, Navarinou 13A, 10680 Athens, Greece

Full list of author information is available at the end of the article

\section{Introduction}

Science education should contribute to increase students' scientific literacy and improve the capacity of understanding science and the processes of producing

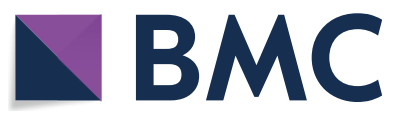

(c) The Author(s) 2021, corrected publication 2021. This article is licensed under a Creative Commons Attribution 4.0 International License, which permits use, sharing, adaptation, distribution and reproduction in any medium or format, as long as you give appropriate credit to the original author(s) and the source, provide a link to the Creative Commons licence, and indicate if changes were made. The images or other third party material in this article are included in the article's Creative Commons licence, unless indicated otherwise in a credit line to the material. If material is not included in the article's Creative Commons licence and your intended use is not permitted by statutory regulation or exceeds the permitted use, you will need to obtain permission directly from the copyright holder. To view a copy of this licence, visit http://creativecommons.org/licenses/by/4.0/. The Creative Commons Public Domain Dedication waiver (http://creativeco mmons.org/publicdomain/zero/1.0/) applies to the data made available in this article, unless otherwise stated in a credit line to the data. 
this knowledge, to ensure more citizens can apply these concepts in their daily lives and participate in scientific debates and discussions (USA National Research Council [NRC], 2007 and 2012). School curricula should be aligned with this goal. The school curriculum represents "the expression of educational ideas in practice" (Prideaux 2003, p.326). Therefore, the learning goals that a country wants its students to achieve and the skills it wants them to develop are expressed and included in its school curriculum. Different countries consider different goals and skills to be more important than others, and for this reason it is expected that curricula would vary in both type and structure (Scholl 2012). There is much discussion in the literature concerning the definition of a school curriculum (Young 2014; Bybee 2003) and its role in education (Burrill et al. 2015). If a scientific theory needs to be widely taught, understood, and accepted by the students and future citizens of a country, it should be included in the national curriculum. Curriculum may be considered a set of official policy documents delivered to teachers and typically created by the relevant ministry of education and/or other state authorities (formal curriculum) (Sanders and Makotsa, 2016). These include all the necessary topics that a teacher should teach and some guidelines on how to do so. If a scientific theory and all its associated concepts are not included in the curriculum, then students may not have the chance to learn about it at school.

Evolution is universally acknowledged as one of the most important scientific concepts and as the unifying theme in biology. Since numerous broad themes in the field of biology are threaded and held together by the theory of biological evolution, several researchers argue that understanding this theory is necessary for scientific literacy (Fowler and Zeidler 2016). Indicative of this relevance, the U.S. National Academy of Sciences (NAS) states that "few other ideas in science have had such a far-reaching impact on our thinking about ourselves and how we relate to the world" (NAS, 1998, p.21) and that "the teaching of evolution should be an integral part of science instruction" (NAS, 1999, p.2). According to the USA NRC (NRC, 2012) evolution should be considered one of the four key concepts in biology to be explored from kindergarten onward, with increasing complexity. This is supported by several researchers that emphasize the need to develop learning progressions for teaching evolution, which should be evident from the curricula and textbooks from primary education and across biology topics (e.g., Prinou et al. 2011; Vaughn and Robbins 2017).

In fact, the study of evolution promotes inter and intradisciplinary links, allowing students to interrelate concepts from biological, physical, and Earth and space sciences and use them to achieve a better understanding of the world around them, as well as to address new problematic situations (NRC 2012). Evolution is related with several daily life experiences-from explaining biodiversity, including the ecosystems inside our species, to drug resistance by bacteria, fleas or mosquitos-and a basic understanding of evolutionary processes is fundamental to address a number of key societal problems such as biodiversity loss, climate change, health or food security (Carroll et al. 2014), resistance to antibiotics and biocides and pandemics (Lederberg 1988). In addition, there is a connection between understanding evolution and negotiating societal problems. Sadler (2005), for example, found that, while examining the informal reasoning of biology majors on scenarios based on genetic engineering socio-scientific issues, their understanding of evolution strongly influenced their decision-making. Furthermore, a deeper engagement with evolution and its understanding can develop a greater knowledge of scientific and evidence-based thinking (Heddy and Nadelson 2012) and it also provides an effective context for developing a deep understanding of the Nature of Science (NoS) (Nelson, et al. 2019), which is important for promoting science literacy (Holbrook and Rannikmae 2007).

Despite its central importance in understanding biological systems and addressing some individuals' daily life and social problems, evolution is still not well understood (or even accepted) by a large part of society, a pattern that is observed across different developmental stages, countries, cultural and religious backgrounds (Alters and Nelson 2002; Asghar et al. 2007; Athanasiou et al. 2012; Athanasiou and Mavrikaki 2013; Athanasiou and Papadopoulou 2012; Blackwell et al. 2003; Ehrlinger et al. 2008; Kruger and Mueller 2002; Miller et al. 2006, Nehm and Reilly 2007; Nehm et al. 2009a, b; Prinou et al. 2008 and 2011; Sieckel and Friedrichsen 2013; To et al. 2017; van Dijk and Reydon 2010). There are several explanations for this persistent and cross-cultural lack of evolutionary understanding including, among others:

- The presence of "cognitive bias" that lead to evolution misconceptions (Gelman 2003; Shtulman 2006; Evans 2008; Sinatra et al 2008; Kelemen 1999; Kelemen et al. 2013; Kelemen 2012; Rottman et al. 2017)

- The fact that evolutionary science integrates knowledge, norms and methods from distinct disciplines such as geology, archaeology, and subdisciplines within biology such as genetics and ecology among others (Gould 2002)

- The difference of meanings between common and scientific language, such as "adapt", "adaptation", "pressure" and "fitness", among other words, that further strengthens misconceptions (Alters and Nelson 2002; Hull 1995; Rector et al., 2013) 
- The perceived conflict between evolution and religious, political and personal believes (Asghar et al. 2007; Boujaoude et al. 2011; Chuang 2003; Griffith and Brem 2004; Goldston and Kyzer 2000)

- Teachers' lack of preparedness to teach about this subject (Prinou et al. 2011; Yates and Marek 2014; Venetis and Mavrikaki 2017; Betz et al. 2019; Gresch and Martens 2019; but see Plutzer et al., 2020 for encouraging results)

The ways that educational resources, such as textbooks and school curricula, are produced may have further contributed to this pattern. In fact, in many textbooks, references to evolution and evolutionary concepts are fragmented and limited to particular chapters (Nehm et al. 2009a, b; Prinou et al. 2011) and some even reinforce common misconceptions (Prinou et al. 2011). To study the impacts of distinct countries' curricular designs and consequent understanding of evolution by students, comparative analyses are needed. Although the acceptance and literacy about evolution has shown to vary greatly among countries (Miller et al. 2006), few studies have analysed the effect of countries' curricula on public evolution literacy. The study of Pinxten et al. (2020) supports the hypothesis that an earlier introduction of evolution in science curricula, and a more in-depth and transversal exploration of evolutionary ideas, may help to increase both understanding and acceptance of evolution. Few curricula analyses regarding the coverage of evolutionary concepts are available in the literature, and these mostly analyse the curricula based on a general assessment of the presence or absence of the topic of evolution (Barberá et al. 1999; Tidon and Lewontin 2004), of some special topics (e.g. Quessada and Clement 2011), or the relationship between religious and scientific views (Asghar et al. 2010). However, none of these examined which major foundational and key concepts required for evolution understanding were present from the first school years onwards. Some researchers partially addressed this problem through the use of an inductive content analysis method, that is an analysis in which the coding scheme is designed based on the analysis of the curriculum and was not predefined based on a certain theoretical framework (e.g. Kuschmierz et al. 2020) or based on mixed methods that included inductive and deductive analysis (Asghar et al. 2015; Sanders and Makotsa 2016). Such research, although very helpful, lacked a framework for comparative analysis. Indeed, comparable research requires a predefined coding scheme (or framework).

Skoog and Bilica (2002) developed such a framework to analyze the science standards of the states of USA, but their focus was on a limited set of overarching evolutionary concepts and not on their foundational concepts, thus limiting their applicability to lower school grades. Some years later, Asghar et al. (2015) provided some very useful results regarding the presence of evolutionary concepts in the biology education curricula from distinct Canadian provinces and territories, basing their template of analysis on the "Understanding Evolution Conceptual Framework" (UECF). The UECF, which was developed "by a team of teachers and scientists making use of resources such as the Atlas of Science Literacy, Benchmarks of Science Literacy, and the National Science education Standards" (Scotchmoor and Thanukos 2007, pp. 232-3), is the result of a collaborative project of the University of California Museum of Paleontology and the National Center for Science education (Understanding Evolution, 2020). UECF includes the foundational as well as the advanced concepts needed to develop a sophisticated understanding of evolutionary theory (Asghar et al. 2015). It is divided into five dimensions: History of life, Evidence of evolution, Mechanisms of evolution, Nature of science, and Studying evolution. Each dimension is further developed into core ideas appropriate for each grade (K-16). Finally, each core idea is divided in subsets of related evolutionary ideas. UECF, according to its creators, is "a list of conceptual understandings regarding evolution, aligned across grade levels to help instructors identify age-appropriate learning goals for their students and understand how concepts taught at one grade level lay the groundwork for more sophisticated concepts later on" (Understanding Evolution 2020). UECF indicates which evolution concepts and mechanisms students should learn about. It is useful as an analytical framework that identifies the foundational evolutionary ideas in elementary grades, as well as specific concepts and mechanisms concerning evolution in later grades (Asghar et al. 2015). Although UECF cannot be directly used as a curricula assessment tool, it is a useful theoretical basis to inform the design of such tools. This was done by Asghar et al., who developed their own curricula assessment tool based on UECF and on the Canadian Common Framework using the concepts "related to fossils and deep time, natural selection, and human evolution" (Asghar et al. 2015, p.5). Unfortunately, this assessment tool is focused only on a limited set of evolution concepts and the study does not present much information about the assessment tool itself. This prevents other researchers from performing similar analyses. However, Asghar et al. (2015) revealed the usefulness of UECF as an initial basis for the development of a framework that could be used to analyze and compare different countries' curricula.

In this paper we aim to develop a framework (template) supported by validity and reliability evidence that could be used to perform comparative analyses of countries' curricula. 


\section{Framework development methods}

To develop a framework to perform comparative curricula analysis, we started by identifying scientific studies that analysed curricula for their coverage of evolution. A non-systematic search allowed us to identify the studies of Skoog and Bilica (2002) and Asghar et al. (2015). To identify additional studies performing curricula analysis regarding the coverage of evolution we have made two searches in the Web of Science: one using the "evolution" and "curriculum analysis"; a second one with "evolution" and "curricula analysis". From these searches we did not retrieve any papers related with analysis of the curricula regarding the coverage of evolution. Given the scarcity of papers providing a methodological framework to analyse curricula regarding their coverage of evolution, we followed the example of Asghar et al. (2015) and started developing our Framework to Assess the Coverage of biological Evolution by school curricula (FACE) based on UECF.

Content analysis (Bjørnsrud and Nilsen 2011; Erdoğan, et al. 2009; Mkumbo 2009; Seker and Guney 2012) was the selected method to analyze curricula and specifically the "deductive content analysis" as this is "guided by a half-structured or structured analysis matrix" (Kyngäs and Kaakinen 2020, p.23). Based on the UECF we built a system of categories and subcategories-attributing code numbers to each category and subcategory-that we used to proceed with the content analysis. The five knowledge dimensions that UECF includes were considered as the categories for our analysis: i) History of Life, ii) Evidence of Evolution, iii) Mechanisms of Evolution, iv) Nature of Science (NoS) and v) Studying Evolution. The main learning goals that, according to UECF, support learning in these five categories were considered as subcategories. Several studies support the importance of these five categories and their subcategories as we describe below.

\section{History of life}

Exploring and understanding the History of Life allows students to: i) explore distinct temporal scales, a threshold concept that is essential for evolution understanding (Tibell and Harms 2017); ii) understand deep time, a prerequisite to understand macroevolutionary processes that has been proven to be challenging to many students and to predict students' acceptance of evolution (Catley and Novick 2009; Cotner et al. 2010); iii) perceive the historical patterns of temporal scales of natural environmental changes and its correlation with extinction rates and compare those with present day patterns to fully understand the human impact in the environment (Wyner and DeSalle 2020). Aligned with these goals, UECF included learning goals that address distinct time scales (turned into the subcategories 1.1 to 1.5 and 1.7 see Appendix A) including deep time (subcategories 1.1, 1.3), the geological and human induced changes and its impacts on evolution (subcategories 1.3, 1.4 and 1.6) as well as the extinction process (subcategory 1.5).

\section{Evidence of evolution}

Recent work has shown that students' position on the relationship between evolution and creation can be affected, among other factors, by their understanding of the scientific evidence supporting evolution (Yasri and Mancy 2016). In agreement with this evidence, UECF includes several learning goals related with the evidence for evolution (category 2 that includes subcategories 2.1 to 2.6).

\section{Mechanisms of evolution}

Understanding the processes that cause evolution are essential not only to understanding the world around us but also to be able to address current socioscientific issues (Fowler and Zeidler, 2016; Peel et al. 2019). UECF addresses the evolutionary processes in the dimension "evolutionary mechanisms" (category 3 from FACE), which includes not only learning goals that are aligned with the key and threshold concepts proposed by Tibell and Harms (2017) to understand evolution by natural selection (subcategories 3.1 to 3.3 and 3.5 to 3.12; see Appendix A) but also learning goals that specifically address other evolutionary processes such as sexual selection (subcategory 3.7) and drift (subcategory 3.8). Although sexual selection and drift are usually much less often addressed by evolution education research and educational curricula, these play a very important role in species evolution, being fundamental for the understanding of natural world and populations, for the teaching of evolution (Price et al. 2014; Sá-Pinto et al. 2017), and in the case of drift, to address problems such as biodiversity loss (Price et al. 2014).

\section{Studying evolution}

In alignment with recommendations for science educationeducation (NRC 2012) UECF also includes learning goals for students to understand how researchers study evolution and how knowledge from evolutionary biology can be applied in daily life contexts. These learning goals are included in the dimension "Studying Evolution" which was turned into our category 4 (with subcategories 4.1, 4.2 and 4.3).

\section{Nature of science}

Finally, UECF also addresses students' understanding about the nature of science (NoS), which has been considered very important for effective science education, and evolution education in particular (e.g. Freeman et al. 
2014; Handelsman et al. 2006; Labov et al. 2009; Singer et al. 2012; Wieman 2014). Several studies (e.g. Rudolph and Steward 1998; Lombroso et al. 2008; Sinatra et al. 2008; Scharmann 2018; Nelson et al. 2019) show a direct correlation between accepting evolution and understanding NoS. This means that if the curricula are made with the purpose of students to not only know but also to accept evolution, then paying attention to NoS gains an extra importance. This importance was recognized by the US National Academy of Sciences, and the UECF authors. NoS was turned into our category 5 (with subcategories 5.1 to 5.5 aligned to dimensions of NoS proposed in the Appendix H of NRC 2013).

This initial version of the Framework for the Assessment of school Curricula on the presence of Evolutionary concepts (pre-FACE) was initially piloted in the Italian curriculum. This curriculum was chosen because its learning goals are phrased in a complex, sometimes ambiguous wording, allowing different possible interpretations. Therefore, it would be ideal for revealing possible gaps or weaknesses of the pre-FACE as a framework for analyzing curricula.

We are aware that we analyze the "latent content" of evolution concepts in the curriculum, as "the locus of meaning is in the content but must be inferred by recognising a pattern across elements" (Potter and Levine-Donnerstein 1999, p. 261). In our case the unit of analysis was the "meaning unit" - "the constellation of words or statements that relate to the same central meaning" (Graneheim and Lundman 2004, p. 106)-inside the learning goals expressed in a curriculum. Each learning goal expressed in the curriculum was considered as one meaning unit, although in some rare cases a learning goal could simultaneously address two different learning goals regarding evolution learning. One example is a goal that is asking students to "relate the consequences of antibiotic misuse with increased bacterial resistance". This requires students to understand that anthropogenic environmental changes and biological evolution are linked (subcategory 1.4), but also that evolution can be directly observed (subcategory 2.2). So, a learning goal like this includes two meaning units and each meaning unit was coded separately. For reasons of text economy from now on when we refer to learning goals we are in fact referring to meaning units regarding the content analysis.

Validity evidence was gathered following the steps proposed by Potter and Levine-Donnerstein (1999) (Table 1) and suggestions were made on the "appropriateness, meaningfulness, correctness, and usefulness" of our framework according to our results (Fraenkel et al. 2012, p. 147).

Three Italian coders analyzed the Italian curriculum and also translated its goals into English. Two non-Italian coders analyzed the translated learning goals using the pre-FACE. We chose to include international codersbesides the Italian ones-so that we would ensure that the coders would see the curriculum for the first time. Working along with the coders on the Italian curriculum to spot any inconsistencies in the framework or overlapping categories and taking under consideration the critique of Hanisch and Eirdosh (2020), we made some adjustments to the pre-FACE in order to: $i$ ) join some subcategories that were redundant and/or returned overlapping results; ii) include guidelines to clarify the conditions under which a learning goal should, or should not, be included in a given subcategory.

\section{Table 1 Steps followed to ensure validity}

\begin{tabular}{|c|c|}
\hline Steps ensuring the validity in the latent pattern content analysis* & Steps ensuring the validity in our research \\
\hline $\begin{array}{l}\text { Develop a coding scheme that guides coders in the analysis of content. } \\
\text { If the scheme is faithful to the theory in its orienting coders to the } \\
\text { focal concepts, it is regarded as a valid coding scheme }\end{array}$ & $\begin{array}{l}\text { Our coding scheme was pre-FACE which was developed based on the UECF. } \\
\text { As described above UECF covers the major evolution ideas (see Appendix } \\
\text { A) and has also been used by Asghar et al. (2015). Therefore, using this as a } \\
\text { basis enhances the validity of our coding scheme }\end{array}$ \\
\hline Coders have to recognise patterns in the text & $\begin{array}{l}\text { Coders had to recognise patterns in the curriculum }=\text { the presence of the } \\
\text { concepts of the pre-FACE in the curriculum under examination }\end{array}$ \\
\hline $\begin{array}{l}\text { Assess the decisions made by coders against some standard (norm). If } \\
\text { the codes match the standard for correct decision making, then the } \\
\text { coding is regarded as producing valid data. We look at the pattern of } \\
\text { agreement that shows at least } 80 \% \text { of the coders making the same } \\
\text { coding. This is a high degree of agreement, and this sets a fairly con- } \\
\text { sistent norm. It means that in our analysis the codes were effective in } \\
\text { assessing what it was intended to assess (validity) and this would be a } \\
\text { widely held judgment (reliability) }\end{array}$ & $\begin{array}{l}\text { Coders (experts with diverse profiles and expertise in the field of biology and } \\
\text { education -some are experts in evolutionary biology, science education } \\
\text { and science communication and some are elementary/secondary biology } \\
\text { teachers or elementary school/biology teachers' trainers), some working } \\
\text { independently and some not, provided the coding. The independent cod- } \\
\text { ing of the data ensured that all meaning units would be identified and that } \\
\text { none was left outside, that is, all learning goals referring to evolution are } \\
\text { included. Codes provided by the coders were compared and the interraters' } \\
\text { (intercoders') agreement assessed by using Krippendorff's alpha coefficient } \\
\text { (Krippendorff 2011). Acceptable results mean a widely held judgment: } \\
\text { anyone who would read the same extract of the curriculum would be led } \\
\text { to the same results regarding which evolution concept was covered }\end{array}$ \\
\hline
\end{tabular}


Our framework, at this point the "pre-FACE-2", consisted of the same five categories as the UECF, namely i) History of Life, ii) Evidence of Evolution, iii) Mechanisms of Evolution, iv) Studying Evolution, v) Nature of Science (NoS), but resulted in having fewer subcategories than in the beginning of the analysis. Based on this framework we performed the following analysis. Each subcategory was assigned a number where the first digit identifies the main category to which an idea belongs, and the next digit(s) identifies the specific subcategory (see Table 2).
To characterize a learning goal, a coder should consider at first the category in which it fits, then decide about the specific subcategory, and finally record every occurrence in the analyzed curriculum.

\section{Data used for the development of the framework}

Within the European context exists a wide range of curricula designs and traditions. In Scandinavian countries and in the UK, school curricula are designed in a highly general form, only mentioning general topics for the schools and teachers themselves to be the responsible

Table 2 Conceptual framework for the analysis of school curricula regarding evolution (pre-FACE-2*)

\begin{tabular}{|c|c|}
\hline Category & Subcategrory \\
\hline \multirow[t]{7}{*}{ 1. History of life } & 1.1 Life has been on Earth for a long time \\
\hline & 1.2 Present day life forms are related to past life forms \\
\hline & $\begin{array}{l}\text { 1.3 Large scale environmental changes (caused by geological, geophysical, astronomical factors) and biological evolution } \\
\text { are linked }\end{array}$ \\
\hline & 1.4 Anthropogenic environmental changes and biological evolution are linked \\
\hline & 1.5 Many life forms that once existed have gone extinct \\
\hline & 1.6 Rates of evolution vary \\
\hline & 1.7 Life forms/species/ change through time \\
\hline \multirow[t]{6}{*}{ 2. Evidence for Evolution } & $\begin{array}{l}\text { 2.1 Similarities and/or differences among existing organisms (including morphological, developmental, and molecular } \\
\text { similarities) provide evidence for evolution }\end{array}$ \\
\hline & 2.2 Evolution can be directly observed \\
\hline & 2.3 The fossil record provides evidence for evolution \\
\hline & 2.4 The geographic distribution of extant species provides evidence for evolution \\
\hline & 2.5 Artificial selection provides evidence for evolution \\
\hline & 2.6 Organisms' features, when analysed in relation to their environment provide evidence for evolution \\
\hline \multirow[t]{12}{*}{ 3. Mechanisms of Evolution } & 3.1 Evolution is often defined as a change in allele frequencies within a population \\
\hline & 3.2 There is variation within a population \\
\hline & 3.3 Living things have offspring that inherit many traits from their parents but are not exactly identical to their parents \\
\hline & 3.4. Evolution occurs through multiple mechanisms \\
\hline & 3.5. Natural selection acts on the variation that exists in a population \\
\hline & 3.6 Inherited characteristics affect the likelihood of an organism's survival and reproduction \\
\hline & 3.7 Sexual selection occurs when selection acts on characteristics that affect the ability of individuals to obtain mates \\
\hline & 3.8 Genetic drift acts on the variation that exists in a population \\
\hline & $\begin{array}{l}\text { 3.9 Fitness is reproductive success - the number of viable offspring produced by an individual in comparison to other } \\
\text { individuals in a population/species }\end{array}$ \\
\hline & 3.10 Species can be defined in many ways \\
\hline & 3.11 Speciation is the splitting of one ancestral lineage into two or more descendant lineages \\
\hline & 3.12 Evolution does not consist of progress in any particular direction \\
\hline \multirow[t]{3}{*}{ 4. Studying evolution } & 4.1 Scientists study multiple lines of evidence about evolution \\
\hline & 4.2 In everyday life we can find applications of evolutionary biology \\
\hline & 4.3 Classification is based on evolutionary relationships \\
\hline \multirow[t]{5}{*}{ 5. Nature of Science } & 5.1 Science is a human endeavor (achievement) \\
\hline & 5.2 Science provides explanations for the natural world \\
\hline & 5.3 Science is based on empirical evidence \\
\hline & 5.4 Scientific ideas can change through time \\
\hline & 5.5 Scientific theories are built through a transparent collective endeavor \\
\hline
\end{tabular}


executors of content. For example, in the official Norwegian curriculum, evolution is barely mentioned, and officials are trusting teachers on how the formal content should be adapted and delivered to the students (Udir 2013 and 2020). It is self-evident that this kind of curricula were not suitable to be analyzed with the proposed framework. Thus, in this study we chose among a specific tradition of curriculum-development that is characterized by a more detailed prescription level; this fits many European countries but does not aim to reflect the whole range of European curricula traditions. Four European countries' curricula of this kind (Greece, Italy, Portugal and Slovenia) were used to test the developed framework.

Given the differences between countries' school systems, we decided to analyze grades 1-9 Biology or Science curricula, or other subjects in which Biology is taught, if the latter did not exist as a separate subject in the school curriculum of a given school grade/country. An exception was made for Italy, for which we analyzed grades $1-10$, as the official curriculum considers the 9th and 10th grades together. Although important evolution learning goals may be addressed in Geography, Geology, or History, the learning goals of these disciplinary fields were only analysed if they were taught in the same discipline that also addressed Biology learning goals.

In three out of four countries (i.e., Portugal, Slovenia and Greece) 9th is the grade until which all students share the same compulsory subjects and programs. After the 9th grade (after 8th grade in Italy), students are usually allowed to choose distinct educational branches, some of which do not include any biological discipline (information about the official documents analyzed and the distinct educational systems provided in Appendix B).

In many countries, although evolution is explored more in depth in higher grades, several organizations and researchers argue for the inclusion of evolutionary ideas starting in the first school years (Campos et al. 2013; Emmons et al. 2017; Kelemen et al. 2014; NRC 2012). This perspective motivated developing a framework for curriculum analysis that could be applied to lower school grades to study and guide curricula construction.

\section{Reliability and coding process}

To perform reliability tests in content analysis (Krippendorff 2004, p. 212, 219), it is important to use "several researchers with diverse personalities"-like the authors of this paper who are characterized by various professional and educational profiles and in many cases were coders. The coders worked in differing environments (i.e. different origins of coders in our case) and demonstrated reproducibility (intercoder reliability; i.e. 'two or more individuals, working independently of each other, applying the same recording instructions to the same units of analysis'; Krippendorff 2004, p. 219). More than one coder applied the same coding scheme to the same units of analysis; a minimum of two coders from each country (local coders) independently read the curriculum of their country and identified any evolutionary goals they could find in these documents. These coders generated a table where each learning goal would occupy a cell in a line (with very few exceptions where a learning goal could include more than one meaning unit, as explained above). In the cell right next to it they were asked to write the translation of this text in English, which was checked by the rest of the national team members to be consistent with the meaning of the initial text. This procedure allowed international coders (one or two foreign coders who had access only to the learning goals but not to the coding) to contribute a "blind" analysis. A "national coordinator" from each country gathered all coders' results in one file (presented in Table 3) and gathered reliability evidence. After that, he/she (i) organized meetings with his/ her country's local coders to discuss results, (ii) identify cases in which many disagreements occurred, and (iii) propose possible changes to be included in the framework to address these problems. The problems and solutions found in each country were then discussed by the team of national coordinators who produced changes to the FACE.

The phases of FACE development are summarized in Fig. 1. The reliability of all coders for each curriculum was tested by Krippendorff's alpha using IBM(c) SPSS 25 and the "syntax kalpha" created by Hayes and Krippendorff (2007).

\section{Results and discussion}

Our goal was to develop a valid and reliable framework for researchers to assess school curricula according to whether they address the ideas, concepts, and mechanisms that are necessary to understand evolution. Across the four countries included in this study we found evidence supporting the presence of learning goals addressing 29 from the 33 subcategories initially included in this analysis (see Table 2 for the framework used and Table 4 for the final version of FACE). Reliability was calculated based on Krippendorff's alpha coefficients (Table 5) and results confirmed coder reliability for each country (Krippendorff 2011).

Although Krippendorff's alpha value was always above the lowest acceptable level of alpha (0.67, Krippendorff 2011), several issues have been identified during the process of the development of the framework. To overcome these problems, following the suggestion of Potter and Levine-Donnerstein (1999, p. 267) to "provide formulae for weighting the different elements so that [future] 
coders will know how to sort through conflicting sets of cues as well as how to handle other coding problems", we provided guidelines to be applied in specific cases. One of them concerns classifying learning goals that relate biological structure and function. In FACE, the subcategory 2.7 'Organisms' features, when analyzed in relation to their environment provide evidence for evolution" (Table 2) was derived from the UECF which provided as an example that "Form is linked to function." However, this subcategory sparked an intense debate in our analysis of the school curricula, mostly when trying to code learning goals that would link structure and function of internal organs without mentioning the organism's living environment. For example, in the Portuguese "Essential Learning Goals Guidelines" it is written: "Relate the organs of the male and female reproductive system with their function" (6th grade; Portuguese Government/Ministry of Education, 2018f p10); "Identify the morphology and anatomy of the heart of a mammal, explaining its main constituents and their respective functions" (9th grade, Portuguese Government/Ministry of Education, 2018i p9); and in the Italian curricula we read: "The student can recognize in her/his organism structures and functions at macroscopic and microscopic levels" (6th8 th grades). To overcome the uncertainty of whether one should attribute subcategory 2.7 in these cases or not we decided that a learning goal fits in this subcategory only if it enables the connection of a particular feature of the organism and its external environment (see Table 4 for the final version of FACE).

Another problem identified during the application of our framework arose with subcategory 3.2-"There is variation within a population"-and subcategory $2.1-$ Similarities and/or differences among existing organisms (including morphological, developmental, and molecular similarities) provide evidence for evolution"-as these were sometimes misused by some of our members, who would consider cases of intraspecific variability belonging to 2.1. To solve this problem, we propose that: i) coders should assess whether the learning goal is focusing on the mechanisms of evolution or the evidence of evolution, as these two subcategories are part of different categories; and ii) the subcategory 2.1 to be applied only for learning goals that mention interspecific diversity or diversity among higher taxonomic levels (example prokaryotic versus eukaryotic cells, see Table 4 for the final version of FACE). 


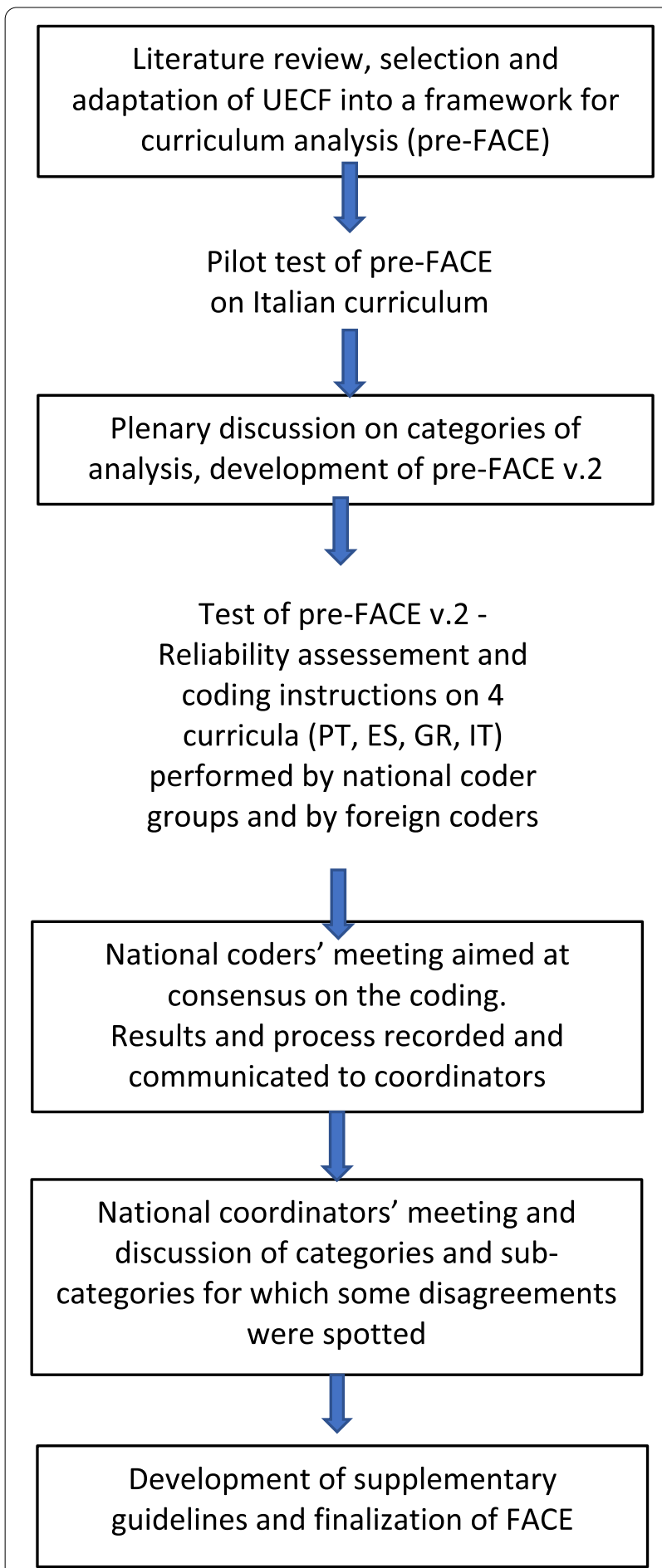

Fig. 1 Description of the process that led to the development of FACE
A similar problem was raised by the interpretation of the subcategory 1.2 "Present day life forms are related to past life forms". When classifying learning goals related with genealogical trees, some coders applied this subcategory to relationships between individuals of the same species. To avoid this, we included a guideline stating that subcategory 1.2 should only be applied to learning goals mentioning distinct species and not distinct individuals of the same species (see Table 4 for the final version of FACE).

All coders referred to goals they identified describing the need for students to engage in scientific practices or recognize the importance of scientific methods, such as:

"Know how to ask questions, raise hypothesis, make inferences, prove results and know how to communicate, recognizing how knowledge is built" (Portugal, Essential Learnings 1st to 4th grades; Portuguese Government/Ministry of 2018a p8; 2018b p9; 2018c p9; 2018d p10 respectively); "implement practical investigations, based on systematic observation, modeling and laboratory/experimental work, to address problems related to terrestrial materials, diversity of living beings and their interactions with the environment. (...) Build scientific explanations based on scientific concepts and evidence, obtained through the performance of diversified practical activities-laboratory, experimental, field-and planned to try to answer formulated problems." (Portugal, Essential Learnings 5th to 6th grades; Portuguese Government/Ministry of Education, 2018e p4; 2018f p4).

"[The student] Explores phenomena with a scientific approach"; "The pupil observes and describes the unfolding of events, asks questions based on personal hypotheses, proposes and realizes simple experiments, with the help of the teacher" (Italy, learning goals for grades 1 st to 5 th).

"Is able to collect qualitative and quantitative data by observing and performing measurements, to record and present them appropriately" (Slovenia, subject Science in 6th and 7th grade).

Although engaging in scientific practices is fundamental to fostering the development of students' scientific literacy (NRC, 2012), goals like these were not directly described in our framework of analysis. But most of the local coders recognized these and similar learning goals as belonging to the subcategories referring to Nature 


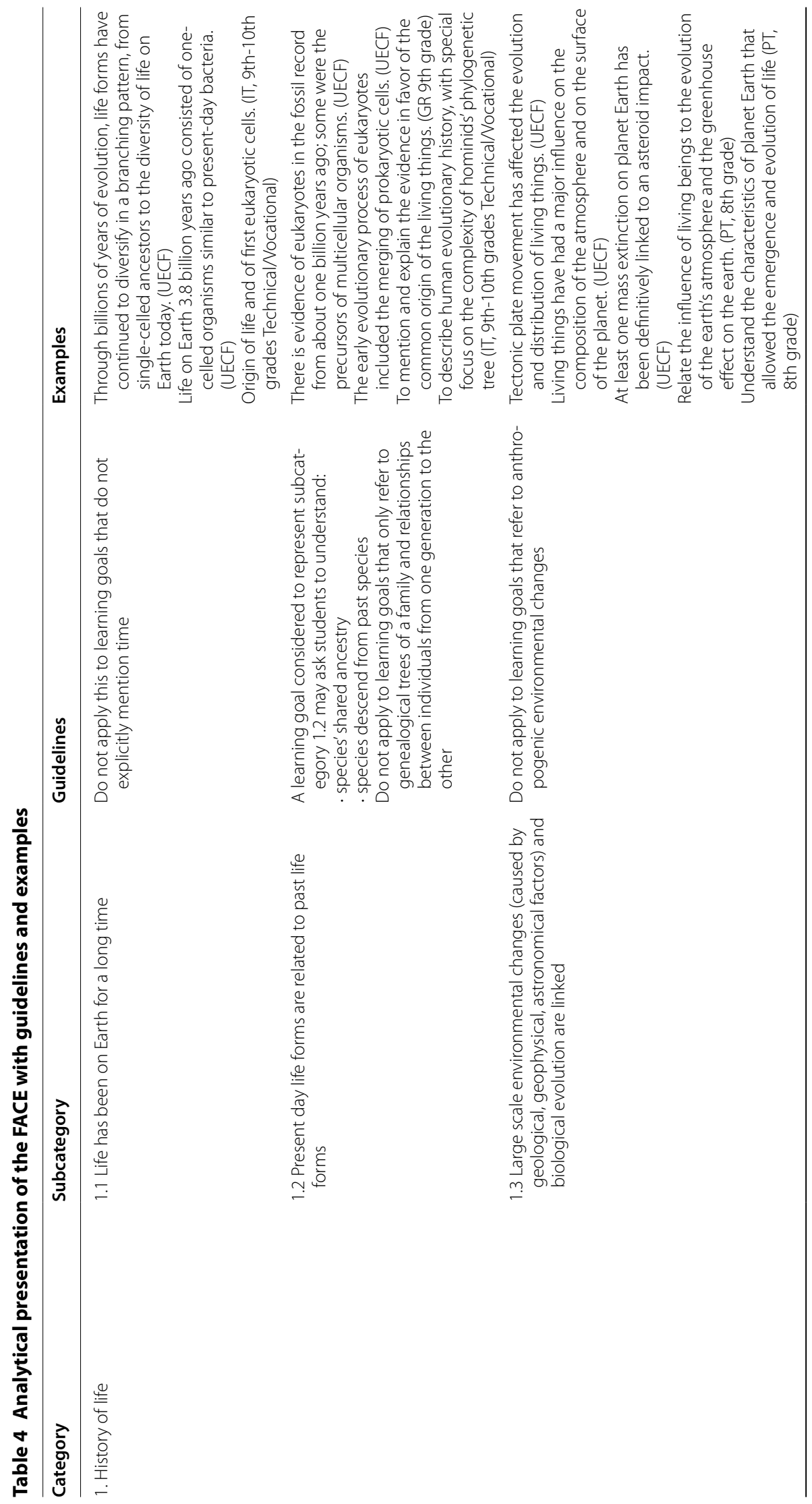




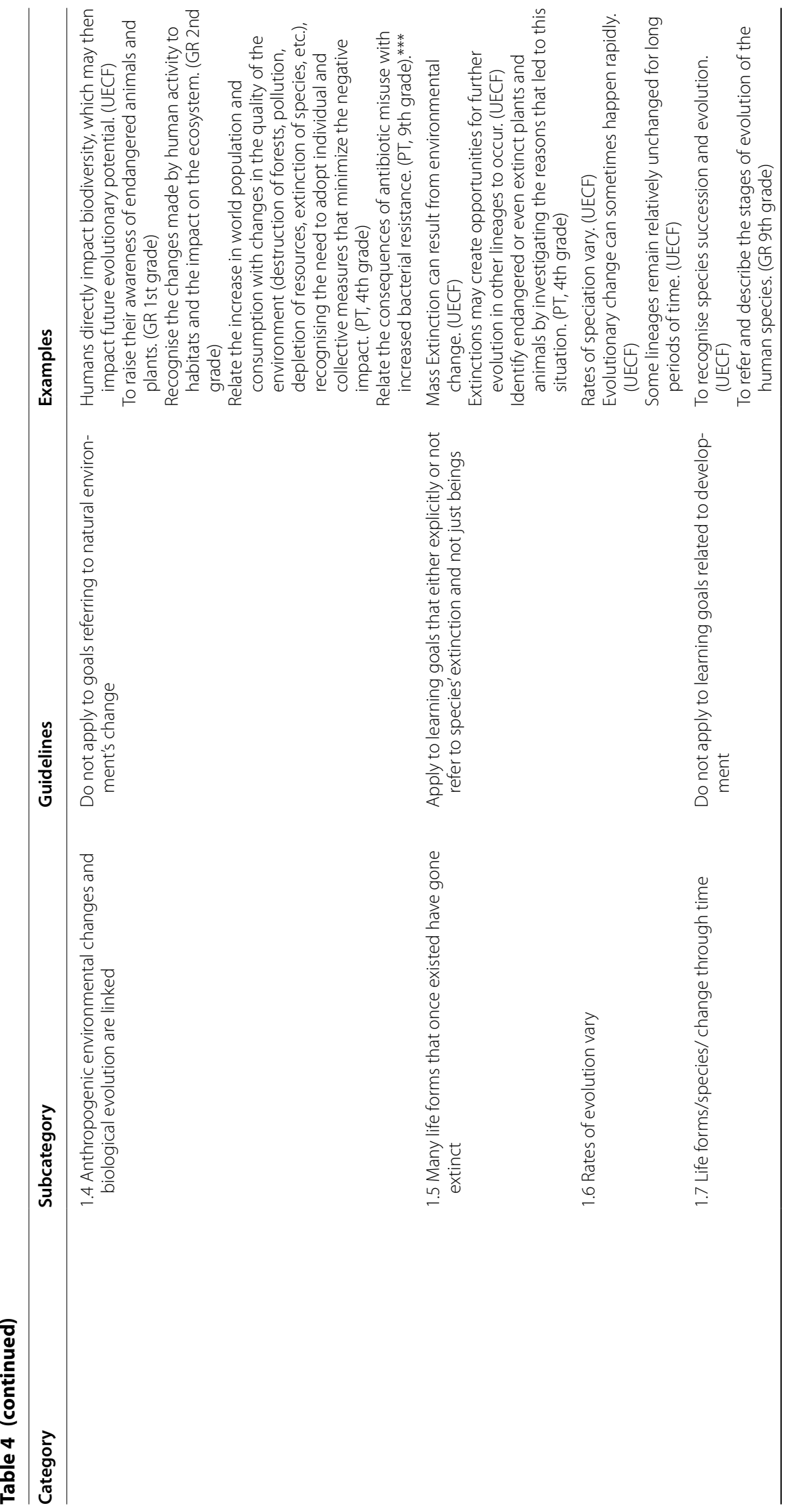




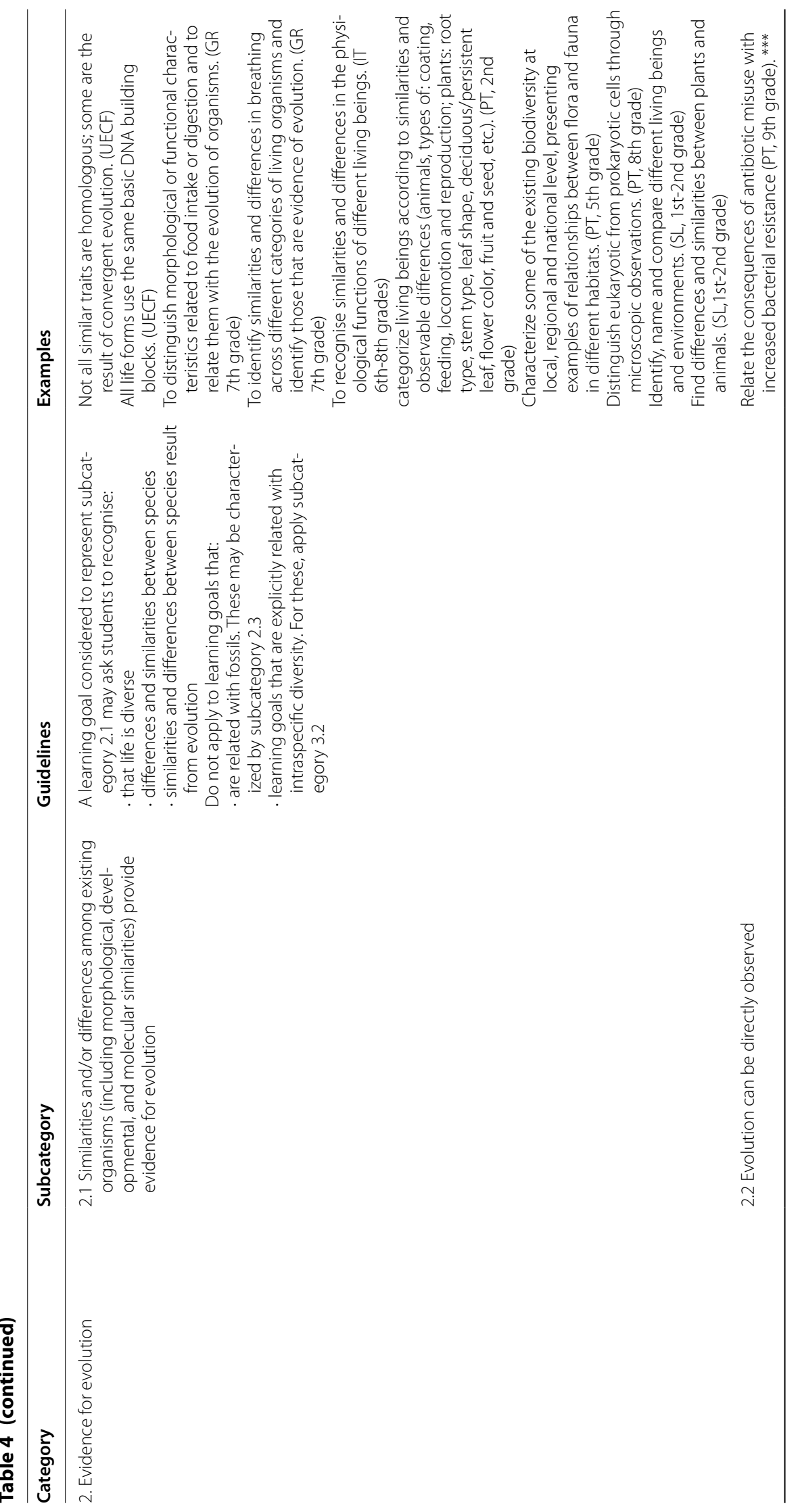




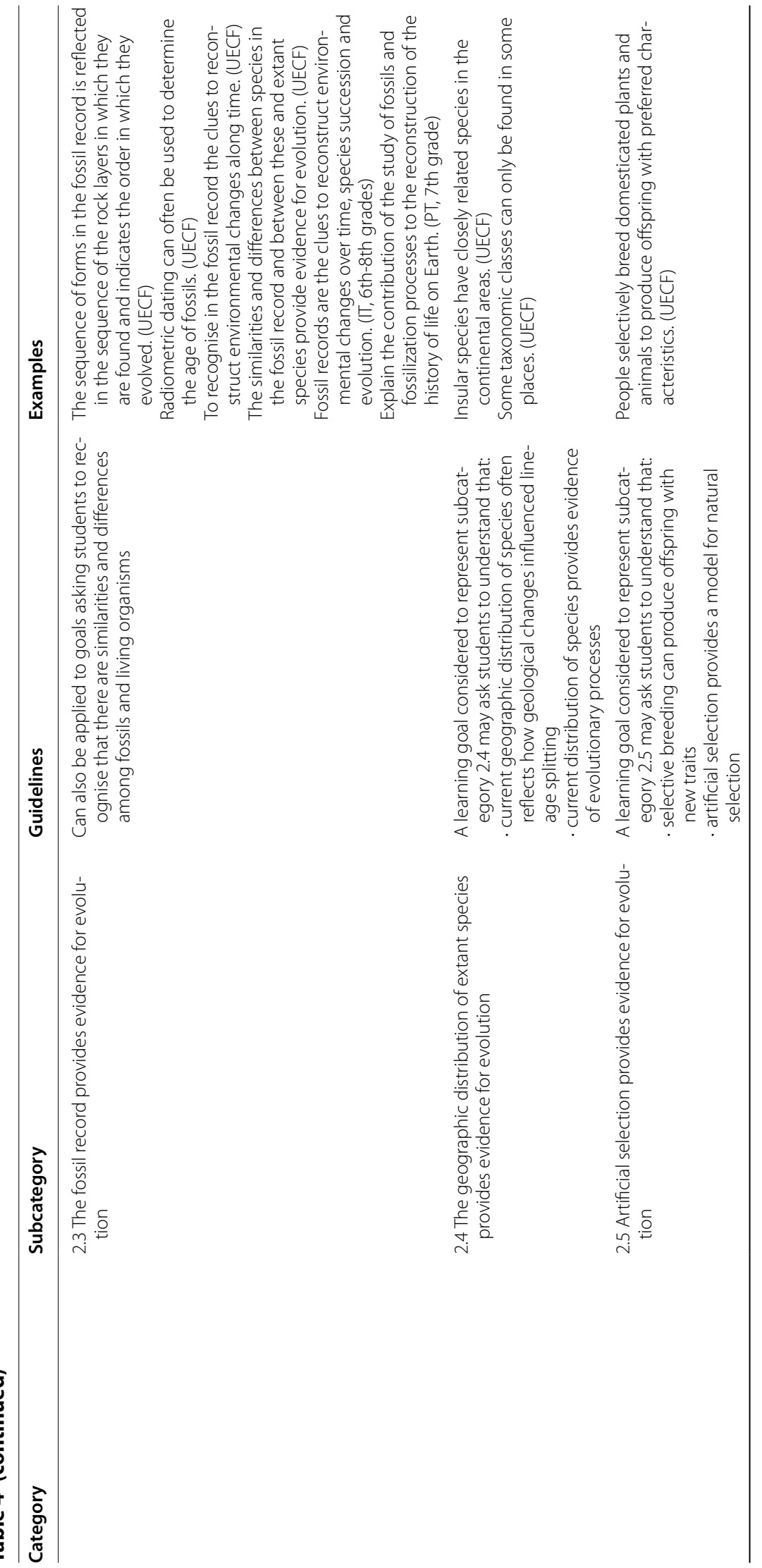




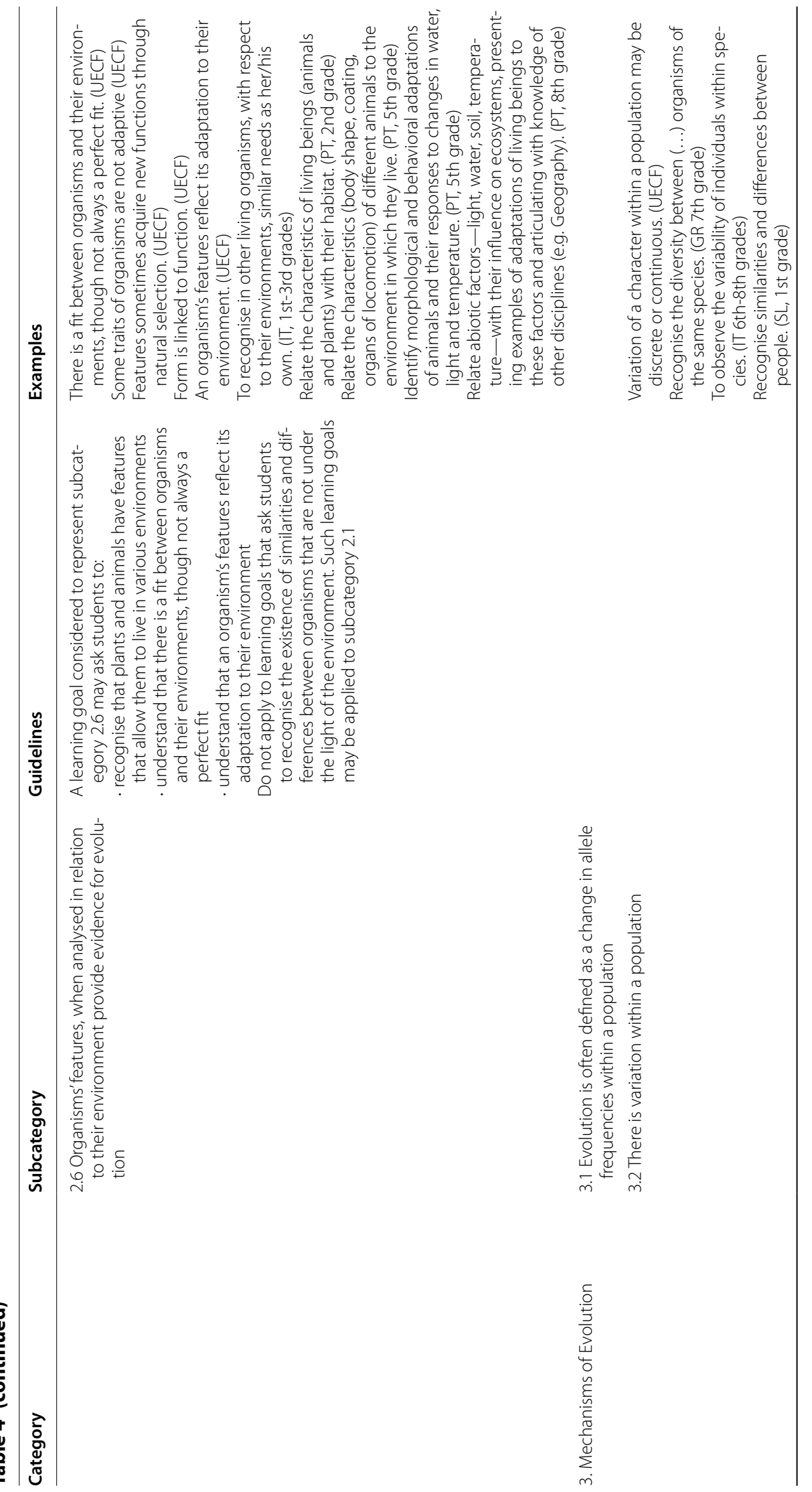


Sá-Pinto et al. Evo Edu Outreach 2021, 14(1):

Page 15 of 27

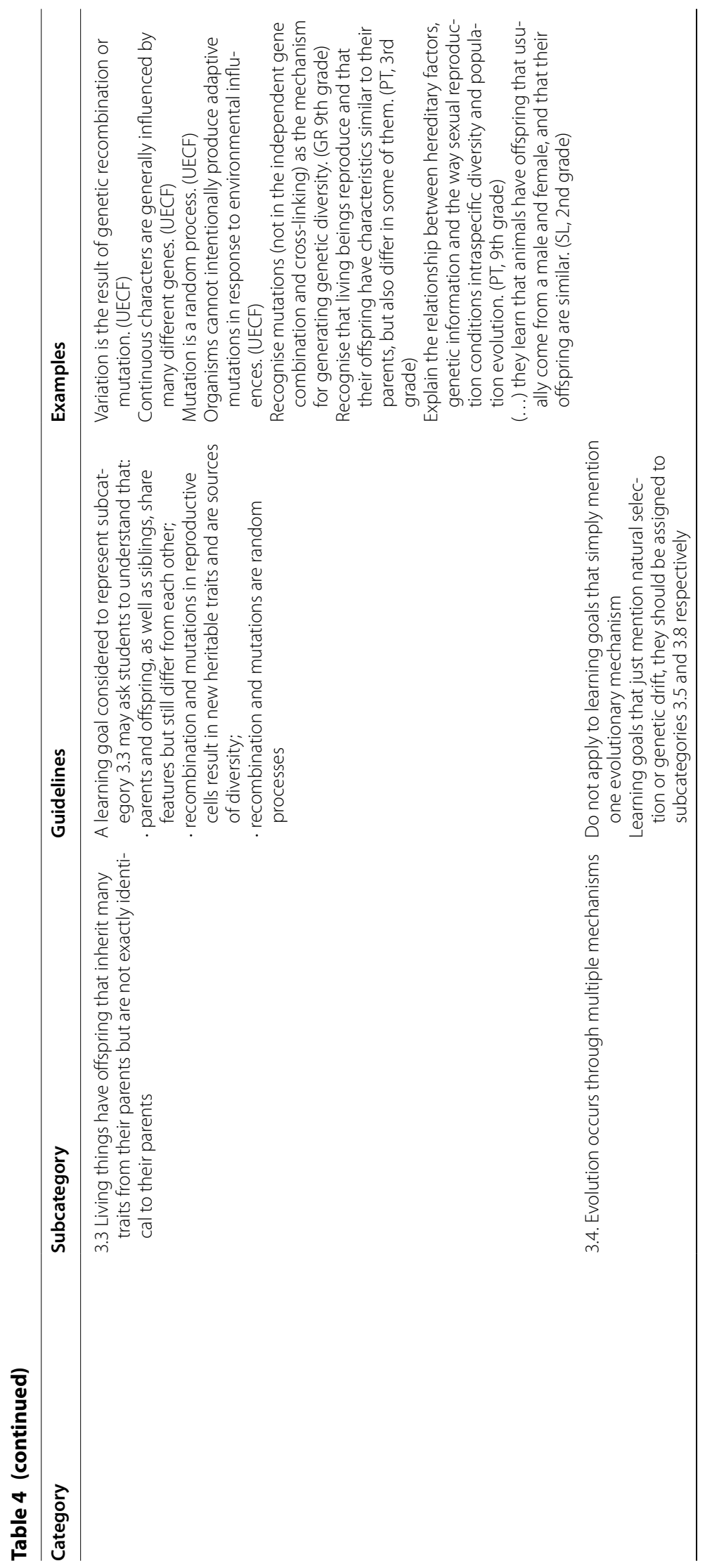




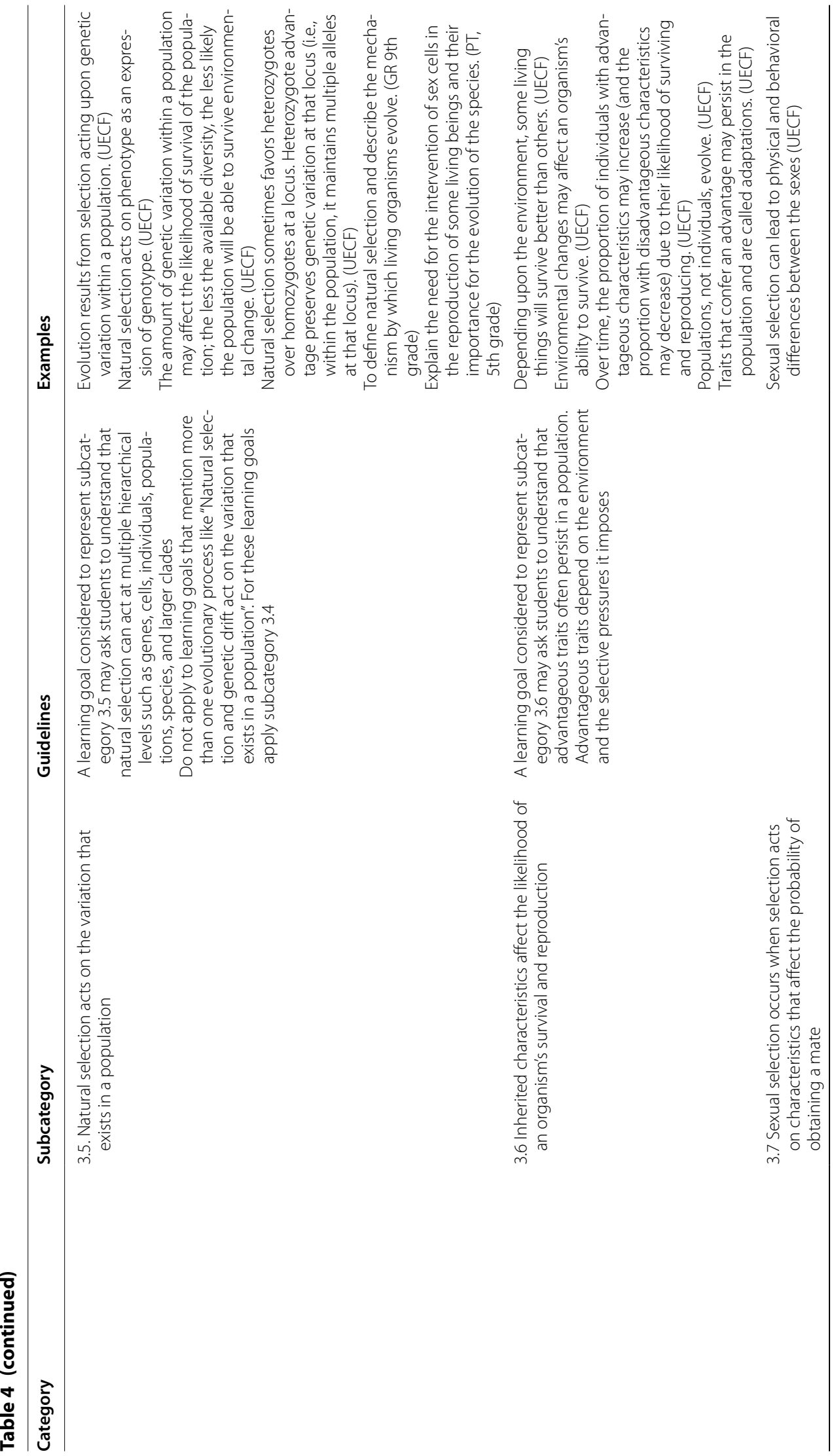




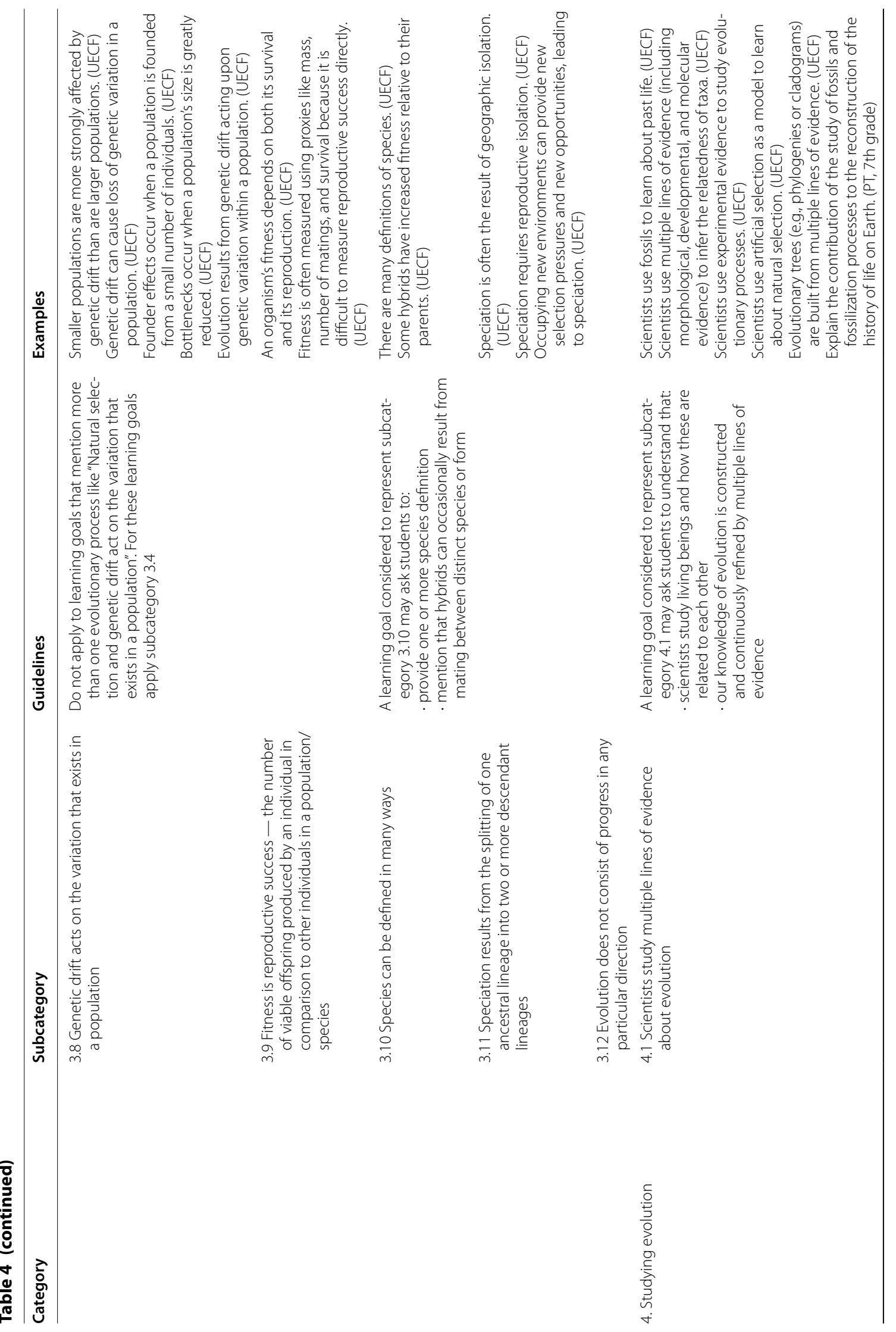




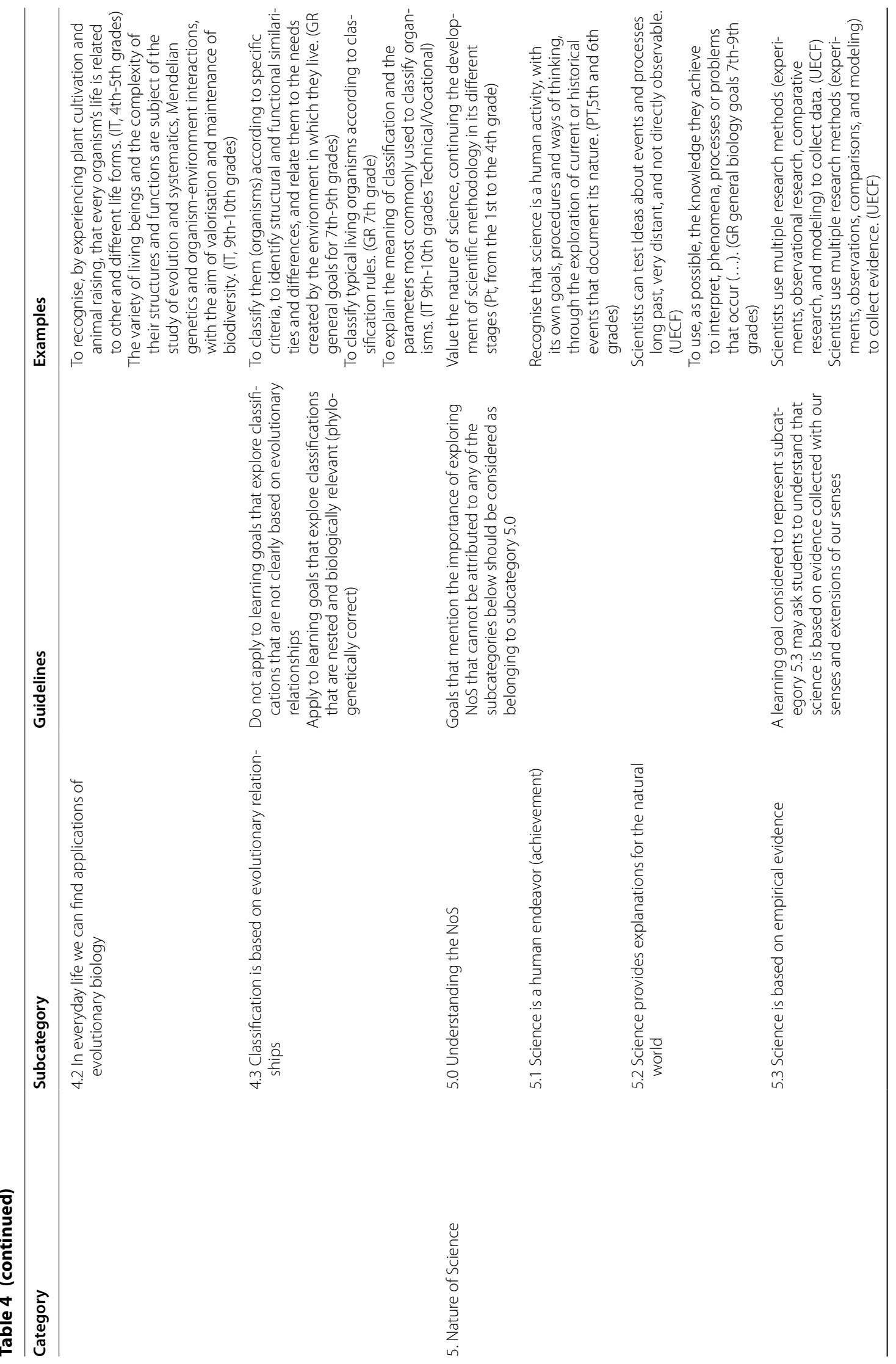




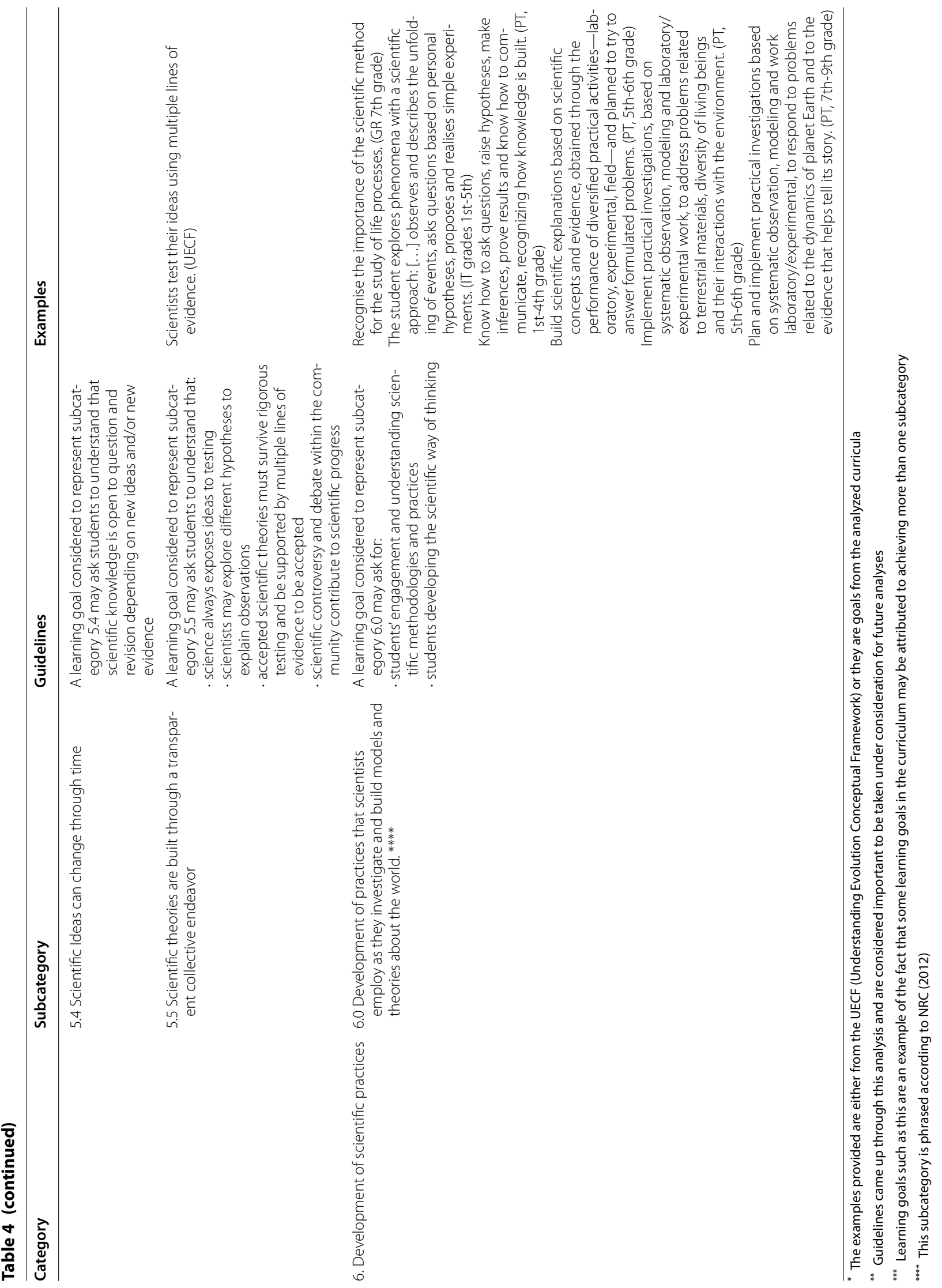


of Science (NoS), mainly based on the assumption that engaging in scientific practices could provide a chance to get better acquainted with the NoS. Furthermore, coding of these learning goals was among the ones with the least consensus between the coders. The confusion between scientific practices, scientific inquiry and NoS is common and longstanding (reviewed by Lederman 2019). However, research results show that students will only learn about the NoS if this is explicitly integrated in the instruction (reviewed by Lederman 2019). To further improve our framework, we recommended the introduction of a new and independent category, which would allow researchers to be more precise and include in this category the learning goals that are related with the development of scientific practices as defined by NRC (2012). Another issue related with NoS was the fact that, in some countries, some official documents mention the importance of valuing the NoS but they do not differentiate the dimensions of the NoS to be learned by students, therefore precluding its assignment to any subcategory of NoS present in our framework. One example of such statements can be found in Portuguese official documents from 1st to 4 th grade that mention in its introductory text, that it is essential to "Value the nature of science, continuing the development of scientific methodology in its different stages" (Portuguese Government/ Ministry of 2018a p3, 2018b p3; 2018c p3; 2018d p4). To overcome this issue, we proposed a guideline suggesting that such statements should be coded as belonging to category 5 (NoS) without detailing the subcategory, therefore they should be coded as subcategory 5.0 (Table 4).

FACE (Table 4) will provide researchers a tool supported by validity and reliability evidence to analyze different countries' curricula. Although countries differ significantly in several aspects (e.g., educational policies, curricula, teachers' education, school textbooks), having a tool supported by evidence to assess coverage of evolutionary key concepts by school curricula could help researchers get a clearer picture for each country. When comparing, for example, the public's acceptance of evolution in different countries (Miller et al. 2006), having an idea about the education that those people have received based on their official school curricula can help to understand the impact of the curricula in public's evolution literacy and acceptance and inform appropriate decisions on educational policies to increase these.

\section{Study limitations and suggestions for further research}

We should highlight that although important evolution learning goals may be addressed in Geography, Geology, or History, the learning goals of these disciplinary fields were only analyzed if these were taught in the same discipline that also addressed Biology learning goals. Furthermore, in our analysis we did not cover the curricula of the school years during which evolution is studied as a major topic or in more depth (in Portugal this is explored in the 11th grade). This may explain why some of FACE's subcategories were not identified in any of the examined curricula (e.g. Rates of evolution vary, Evolution is often defined as a change in allele frequencies within a population, Genetic drift acts on the variation that exists in a population etc.). This did not surprise us because UECF suggests that some of these subcategories should be explored by older students. It is possible that additional problems could arise when using the FACE in upper educational levels. Given this, future work should expand the study of FACE's usefulness in evaluating higher grades' curricula.

FACE (Table 4) could also be used to assess whether the evolutionary concepts are presented in other school subjects' curricula, besides biology, and could also be used to assess their presence in a continuity or in a fragmented fashion. The analysis of Scheuch and Rachbauer (2019) found a fragmentation of evolutionary concepts in Austrian school textbooks, and Nehm et al. (2009a, b) consider fragmentation as a major possible source of misconceptions as it gives students a fragmentary picture of evolution (Sanders and Makotsa 2016). Of course, we should not underestimate the role of a good teacher in overcoming any obstacles posed by the curriculum. Therefore, besides analyses of countries' curricula further studies focusing on teachers, students, textbooks and teaching practices are needed to improve our understanding about how evolution is taught in each country. 


\section{Abbreviations}

FACE: Framework for the Assessment of school Curricula regarding Evolution FC: Fundação para a Ciência e a Tecnologia; GR: Greece; IT: Italy; K-9: Kindergarten to 9th grade; NoS: Nature of Science; NRC: National Research Council (USA); PT: Portugal; SL: Slovenia; UECF: Understanding Evolution Conceptual Framework; UK: United Kingdom.

\section{Acknowledgements}

We would like to thank Efthymia Nikita and Asimakis Talamagas for their valuable comments and therefore their contribution to this deliverable. We would also like to thank the EuroScitizen Steering Committee and specially to Tania Jenkins for their work and support to EuroScitizen WG2.

\section{Author contributions}

EM was responsible for the international coordination of the project. EM, XSP, GR and GT were national coordinators of the project. EM, XSP, GR, GT, BS, $P P, A J, K K, P K S, T N, J B, H D, M G, D C, M P$ were involved in the development of FACE. EM, XSP, GR, GT, AC, BS, BC, PP, CP, MP, TG, KK, PKS, TN, MG performed the curriculum analysis either as local or foreigner researchers. EM led the data analysis. EM, XSP, GR led the writing of the paper and all authors contributed to discussions and to its final version.

\section{Funding}

Xana Sá-Pinto is funded by Portuguese national funds through FCT Fundação para a Ciência e a Tecnologia, I.P., within the scope of the framework contract foreseen in the numbers 4,5 and 6 of the article 23 , of the Decree-Law 57/2016, of August 29, changed by Law 57/2017, of July 19 and through the project UID/CED/00194/2019. Teresa Nogueira was supported by FCT, under the project UID/00329/202 and the contract ALG-01-0145FEDER-028824. Angelica Crottini is supported by the Portuguese National Funds through FCT with the Investigador FCT grant (IF/00209/2014). Costanza Piccoli is supported by FCT PhD Studentship (SFRH/BD/144342/2019). This article/publication is based upon work from COST Action EuroScitizen (CA17127; Working Group 2), supported by COST (European Cooperation in Science and Technology; https://www.cost.eu/).

\section{Availability of data and materials}

The datasets generated during the current study are not publicly available due to the fact that they consist part of a wider project that will present the results of a comparative analysis of European countries'school curricula regarding evolution but are available from the corresponding author on reasonable request. Official papers referring to each country's school curriculum that provided the original data used in this paper are the following: Greek educational system Government's Gazette Vol. B, No. 304/13-03-03 [in

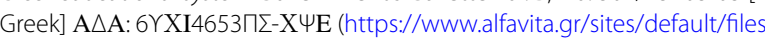
/attachments/didaktea ili.pdf). Portuguese educational system. Portuguese Assembly of Republic (2009). Law n. 85/2009, from 27 of August. https://dre. pt/application/conteudo/488826. Portuguese Government/Decree-Law n.o 55/2018, from 6 july. https://dre.pt/application/conteudo/115652962. Portuguese Government/Ministry of education, Education (2018a, b, c, d, e, f, g, h, i). Italian educational system. Indicazioni nazionali per il curricolo della scuola dell'infanzia e del primo ciclo d'istruzione (D.M. 254 del 16 novembre 2012): http://www.indicazioninazionali.it/2018/08/26/indicazioni-2012/. Indicazioni nazionali riguardanti gli obiettivi specifici di apprendimento concernenti le attività e gli insegnamenti compresi nei piani degli studi previsti per i percorsi liceali (D.M. n 211 del 7/10/2010); Regolamento recante norme concernenti il riordino degli istituti tecnici ai sensi dell'articolo 64, comma 4, del decreto legge 25 giugno 2008, n. 112, convertito dalla legge 6 agosto 2008, n. 133; Regolamento recante norme concernenti il riordino degli istituti professionali ai sensi dell'articolo 64, comma 4, del decreto legge 25 giugno 2008, n. 112, convertito dalla legge 6 agosto 2008, n. 133: http://archivio.pubblica.istru zione.it/riforma_superiori/nuovesuperiori/index.html Slovenian educational system Eurydice (2019). Slovenia overview, https://eacea.ec.europa.eu/natio nal-policies/eurydice/content/slovenia_en. Gov.si. Republic of Slovenia (2020). Programi in učni načrti v osnovni šoli [Programs and syllabuses in compulsory basic school]. Retrieved from https://www.gov.si/teme/programi-in-ucni-nacrt i-v-osnovni-soli/.

\section{Ethics approval and consent to participate}

Not applicable.

\section{Consent for publication}

Not applicable.

\section{Competing interests}

There are no competing interests.

\section{Author details}

${ }^{1}$ Research Centre on Didactics and Technology in the Education of Trainers, Department of Education and Psychology, University of Aveiro, Aveiro, Portugal. ${ }^{2}$ UNICAMearth Group, Geology Section, University of Camerino, Camerino, Italy. ${ }^{3}$ University of Ljubljana Faculty of Education, Kardeljeva ploščad 16, 1000 Ljubljana, Slovenia. ${ }^{4}$ Alpoente, Agrupamento de Escolas de Albufeira Poente, Albufeira, Portugal. ${ }^{5}$ Department of Biology, National and Kapodistrian University of Athens, Athens, Greece. ${ }^{6}$ Milner Centre for Evolution, Department of Biology and Biochemistry, University of Bath, Bath, UK. ${ }^{7}$ Department of Education, University of Cyprus, Nicosia, Cyprus. ${ }^{8}$ Laboratorio di Scienze Sperimentali, Foligno, Italy. ${ }^{9}$ University of Trás-OsMontes E Alto Douro, Vila Real, Portugal. ${ }^{10}$ Ampelokipoi Laboratory Centre for Natural Sciences (EKFE), Athens, Greece. ${ }^{11}$ IPsantarém, Polytechnic Institute of Santarém-School of Education, Santarém, Portugal. ${ }^{12}$ CeiED, Lusófona University, Lisboa, Portugal. ${ }^{13} \mathrm{CIBIO} / \mathrm{InBio}$ InBIO, Universidade Do Porto, Centro de Investigação Em Biodiversidade E Recursos Genéticos, Campus Agrario de Vairão, 4485-661 Vairão, Portugal. ${ }^{14}$ INIAV, National Institute for Agrarian and Veterinary Research, Oeiras and Vairão, Portugal. ${ }^{15} \mathrm{CE3C}$, Centre for Ecology, Evolution and Environmental Changes, University of Lisbon, Lisbon, Portugal. ${ }^{16}$ Department of Early Childhood Education, University of Western Macedonia, Kozani, Greece. ${ }^{17}$ University College of Green Development, Bryne, Norway. ${ }^{18}$ Le Cercle FSER, Paris, France. ${ }^{19}$ Faculty of Education, "St. Kliment Ohridski" University, Bitola, North Macedonia. ${ }^{20}$ Faculty of Science, University of Sarajevo, Sarajevo, Bosnia and Herzegovina. ${ }^{21}$ Chair of Genetics and Evolution, Faculty of Biology, University of Belgrade, Belgrade, Serbia. 22 Faculty of Primary Education, National and Kapodistrian University of Athens, Navarinou 13A, 10680 Athens, Greece.

\section{Appendix A}

See Table 5. 
Table 5 Threshold and key concepts of evolution by natural selection (Tibel and Harms, 2017) and examples of how these are addressed in FACE

\begin{tabular}{ll}
\hline Type of Concept $\quad$ Concept & $\begin{array}{l}\text { Examples of how these concepts are addressed in FACE } \\
\text { (subcategories are identified by their codes and description; } \\
\text { guidelines provided when needed) }\end{array}$
\end{tabular}
guidelines provided when needed)

Threshold concept

Temporal scale

Spatial scale

Probability

Randomness

Key concepts of natural selection: Principle Variation

Origin of variation

Individual variation

Differential fitness
Processes taking place at very long temporal scales:

1.1 Life has been on Earth for a long time

1.3 Large scale environmental changes (caused by geological, geophysical, astronomical factors) and biological evolution are linked 2.3 The fossil record provides evidence for evolution Processes taking place at our species temporal scale:

1.4 Anthropogenic environmental changes and biological evolution are linked

2.6 Artificial selection provides evidence for evolution

Processes taking place in a generation time scale:

3.3 Living things have offspring that inherit many traits from their parents but are not exactly identical to their parents

Processes taking place at diverse time scale:

1.5 Many life forms that once existed have gone extinct

1.7 Life forms/species/ change through time

Large worldwide scale

1.3 Large scale environmental changes (caused by geological, geophysical, astronomical factors) and biological evolution are linked

2.4 The geographic distribution of extant species provides evidence for evolution

Ecosystem/population scale

2.6 Organisms'features, when analysed in relation to their environment provide evidence for evolution

3.5 Natural selection acts on the variation that exists in a population Individuals'scale

3.6 Inherited characteristics affect the likelihood of an organism's survival and reproduction

Cell/molecular scales

3.3 Living things have offspring that inherit many traits from their parents but are not exactly identical to their parents (includes the following guideline: recombination and mutations in reproductive cells result in new heritable traits and are sources of diversity)

3.6 Inherited characteristics affect the likelihood of an organism's survival and reproduction

3.7 Sexual selection occurs when selection acts on characteristics that affect the probability of individuals to mate

3.3.- Living things have offspring that inherit many traits from their parents but are not exactly identical to their parents (guideline: A learning goal considered to represent subcategory 3.3 may ask students to understand that recombination and mutations are random processes)

3.8 Genetic drift acts on the variation that exists in a population

3.3 Living things have offspring that inherit many traits from their parents but are not exactly identical to their parents. (guideline: A learning goal considered to represent subcategory 3.3 may ask students to understand that recombination and mutations in reproductive cells result in new heritable traits and are sources of diversity)

3.2 There is variation within a population

3.5. Natural selection acts on the variation that exists in a population 3.8 Genetic drift acts on the variation that exists in a population

3.6 Inherited characteristics affect the likelihood of an organism's survival and reproduction

3.9 Fitness is reproductive success - the number of viable offspring produced by an individual in comparison to other individuals in a population/species 
Table 5 (continued)

\begin{tabular}{|c|c|c|}
\hline Type of Concept & Concept & $\begin{array}{l}\text { Examples of how these concepts are addressed in FACE } \\
\text { (subcategories are identified by their codes and description; } \\
\text { guidelines provided when needed) }\end{array}$ \\
\hline \multirow[t]{2}{*}{ Key concepts of natural selection: Principle Inheritance } & Heritable traits & $\begin{array}{l}\text { 3.6 Inherited characteristics affect the likelihood of an organism's } \\
\text { survival and reproduction } \\
\text { 3.3 Living things have offspring that inherit many traits from their } \\
\text { parents but are not exactly identical to their parents }\end{array}$ \\
\hline & Reproduction & $\begin{array}{l}\text { 3.7 Sexual selection occurs when selection acts on characteristics that } \\
\text { affect the probability of individuals to mate } \\
\text { 3.9 Fitness is reproductive success - the number of viable offspring } \\
\text { produced by an individual in comparison to other individuals in a } \\
\text { population/species }\end{array}$ \\
\hline \multirow[t]{4}{*}{ Key concepts of natural selection: Principle Selection } & Selection pressure & $\begin{array}{l}3.6 \text { Inherited characteristics affect the likelihood of an organism's } \\
\text { survival and reproduction (Guideline: A learning goal considered } \\
\text { to represent subcategory } 3.6 \text { may ask students to understand that } \\
\text { (...) advantageous traits depend on the environment and selective } \\
\text { pressures it imposes) }\end{array}$ \\
\hline & $\begin{array}{l}\text { Differential survival } \\
\text { and reproduction }\end{array}$ & $\begin{array}{l}\text { 3.6 Inherited characteristics affect the likelihood of an organism's } \\
\text { survival and reproduction }\end{array}$ \\
\hline & Change in population & $\begin{array}{l}\text { 3.1 Evolution is often defined as a change in allele frequencies within } \\
\text { a population }\end{array}$ \\
\hline & Speciation & $\begin{array}{l}\text { 3.11 Speciation results from the splitting of one ancestral lineage into } \\
\text { two or more descendant lineages }\end{array}$ \\
\hline
\end{tabular}

\section{Appendix B \\ Description of each country's school system and the analysed documents \\ Greece}

The Greek educational system consists of preschool education (mandatory), primary education (6 years), secondary education (6 years, from which the 3 of them are mandatory-lower secondary education-and the rest optional and divided to Professional and General studies, which both can lead to exams for tertiary education) and tertiary education (the years depend on the type of studies). The Greek curricula are official documents and teachers have to follow them-only a very small deviation is allowed-and there is only one school textbook for each subject, which is available for free to students of public schools and also can be publicly accessed on the internet. The curricula that are valid today in Greece were published 17 years ago and are only being slightly modified from time to time (Government's Gazette Vol.

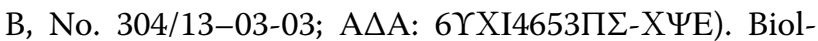
ogy, as a separate subject, exists only in secondary education, whereas in primary Education there are more general courses and teachers with no specialization in science teach these courses. Preschool students are considered to get in touch with nature and their environment and students of primary education get in touch with some biological concepts during their first 4 grades in a course called "Studying the Environment" (referring to manmade and natural environment). During their last two years of primary education a course called Science dedicates about $1 / 3$ of its content to Biology. However, from 2018 an official paper that was administered to schools asked teachers not to teach most of these biological concepts. As a result, Greek students who will graduate compulsory education will have studied biology mainly during their 3 last years and only for $1 \mathrm{~h} /$ week.

\section{Portugal}

In Portugal, compulsory education starts at the age of 6 years old, prior to which pre-school education is available in both private and public schools, but attendance is not mandatory (Portuguese Republic Assembly, 2009). Compulsory education extends for 12 years which include basic education and secondary education. In basic education, the subjects are common to all students (until 9th grade). In secondary education, students can attend either science or humanities courses, which have common and specific subjects for each branch, or they can attend professional courses (Portuguese Government/Decree-Law 55/2018). Basic Education comprises three cycles. The first cycle is attended by students from 6-10 years-old and extends from the 1st to the 4th grade. During this cycle a single teacher is responsible to teach several subjects that include portuguese, mathematics, study of the environment, artistic education, physical education and citizenship and development. 1st cycle students also have to attend English lessons (Diário da Républica Eletrónico/Decree-Law 55/2018). During this cycle, biology education is addressed in the study of the environment learning goals, which aim to develop 
content knowledge and skills in biology, geology, physics, chemistry, geography, history and technology (Portuguese Government/Ministry of Education, 2018a, b, c, d). In the second cycle, from 5 to 6 th grade (11-12y students), and third cycle, from 7 to 9 th grade (13-15y students), each disciplinary field is taught by specialized teachers in that field. Biology is taught in the discipline of Natural Sciences, together with Geology. For all these cycles and disciplinary fields, the learning goals in terms of content knowledge and skills are mostly determined by the national official programs, with the school boards being allowed to determine up to $25 \%$ of the annual standards. The essential learning goals documents detail the content learning and skills that should be developed by all students during basic education. For that reason, in the present study we analysed the essential learning goals of study of the environment (from the 1st to the 4th grade; Portuguese Government/Ministry of 2018a to d) and natural sciences (from the 5th to the 9th grade Portuguese Government/Ministry of Education, 2018e to i).

\section{Italy}

The Italian School System is organized in two cycles. The First Instruction Cycle is composed of Kindergarten, (3 to 6 years, non-compulsory education), Primary School (1st to 5th grade, from 6 to 11 years of age, compulsory education) and Lower Secondary School (6th to 8th grade, from 11 to 14 years of age, compulsory education). The First Instruction Cycle offers the same curriculum to all students. The Second Instruction Cycle is composed of Upper Secondary School (9th to 13th grade). It is compulsory until 16 years of age (9th and 10th grades) and is divided into different school types: Liceo, Technical and Vocational High Schools, each one with further specializations. Liceo High School is a general high school preparing for university, Technical High School prepares for employment but also gives access to university, Vocational High School, is more focused on practical subjects and work experience, but gives access to university too. In Kindergarten and in Primary School, a teacher (generally without a specific academic background) can teach all subject areas, including Biology, present in both segments with different names. In Lower Secondary School, science and mathematics are taught by the same teacher, usually with a biology or a mathematics degree. Science teaching time is officially $3 \mathrm{~h}$ per week. In Liceo High School, Biology is taught within Natural Sciences $(2-3 \mathrm{~h}$ per week) by a teacher with a degree in biology/natural sciences or another related subject. In Technical and Vocational High Schools, Biology is taught as in Liceo, (within Natural Sciences, $2 \mathrm{~h}$ per week) but only in the first two grades, with the exception of some specializations (e.g. agriculture). School curricula are nationwide and regulated at the general level by Ministry of Education guidelines. Teachers are guaranteed a good amount of liberty in teaching and in choosing among many different textbooks.

\section{Slovenia}

In Slovenia, pre-school education is optional. Children can enrol as early as at the age of 11 months and attend it until they start compulsory school. Nine-year compulsory school is divided into three three-year cycles (for students from 6 to 14 years old). It is mandatory, 99\% public, and state-financed. The first six years can be recognised as the primary (ISCED 1) level. Grades 7-9 are internationally recognised as the lower secondary school (ISCED 2). This is followed by the upper secondary school system (ISCED 3) (from two up to five years) (Eurydice, 2019). Biology learning objectives are already included in the curriculum for pre-school education, in one of six programs named Nature. In the nine-year compulsory school biology education is included in four compulsory school subjects: Learning about the environment (1st, 2nd and 3rd grade), Science and Technology (4th and 5th grade), Science (6th and 7th grade), and Biology (8th and 9th grade). The subject "Science" dedicates about $2 / 3$ of its content to biology. Biology education is also a part of upper secondary education in subjects of Biology, Science or Science and Society, depending on the study program. Primary school teachers are teaching all school subjects in the first threeyears cycle and most of the second three-year cycle. In 5 th and 6th grade specialized subject teachers gradually take over teaching subjects. These others teach the subjects Science in 6th and 7th grade and Biology in the 8th and 9 th grade.

Received: 22 September 2020 Accepted: 5 February 2021 Published online: 26 February 2021

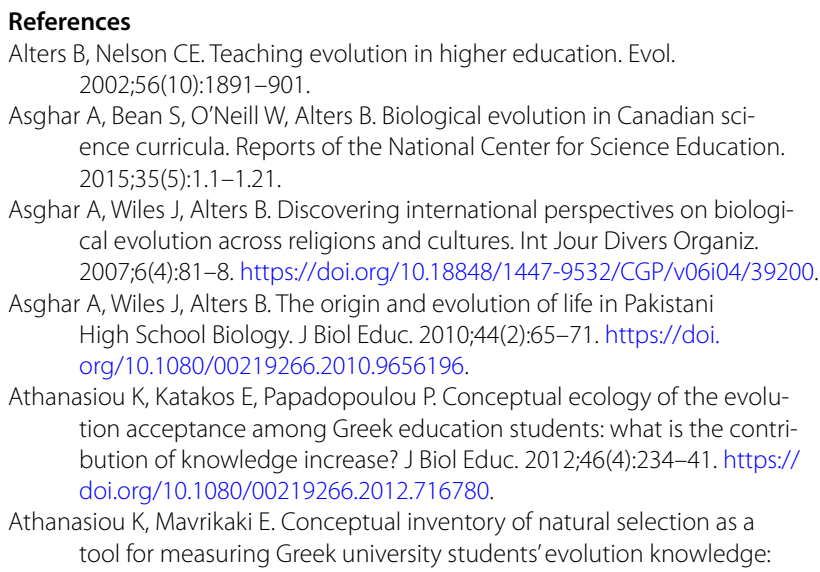
ence curricula. Reports of the National Center for Science Education. 2015;35(5):1.1-1.21.

Asghar A, Wiles J, Alters B. Discovering international perspectives on biological evolution across religions and cultures. Int Jour Divers Organiz. 2007;6(4):81-8. https://doi.org/10.18848/1447-9532/CGP/v06i04/39200.

Asghar A, Wiles J, Alters B. The origin and evolution of life in Pakistani High School Biology. J Biol Educ. 2010;44(2):65-71. https://doi. org/10.1080/00219266.2010.9656196.

Athanasiou K, Katakos E, Papadopoulou P. Conceptual ecology of the evolution acceptance among Greek education students: what is the contribution of knowledge increase? J Biol Educ. 2012;46(4):234-41. https:// doi.org/10.1080/00219266.2012.716780.

Athanasiou K, Mavrikaki E. Conceptual inventory of natural selection as a tool for measuring Greek university students' evolution knowledge: 
differences between novice and advanced students. Int J Sci Educ. 2013;36(8):1262-85. https://doi.org/10.1080/09500693.2013.856529.

Athanasiou K, Papadopoulou P. Conceptual ecology of the evolution acceptance among Greek education students: knowledge, religious practices and social influences. Int J Sci Educ. 2012;34(6):903-24. https://doi. org/10.1080/09500693.2011.586072.

Barbera O, Zanon B, Perez-Pla JF. Biology curriculum in twentieth-century Spain. Sci Educ. 1999;83:97-111.

Betz N, Leffers JS, Thor EED, Fux M, de Nesnera K, Tanner KD, Coley JD. Cognitive construal-consistent instructor language in the undergraduate biology classroom. Life Sci Educ. 2019. https://doi.org/10.1187/ cbe.19-04-0076.

Bjørnsrud $\mathrm{H}$, Nilsen S. The development of intentions for adapted teaching and inclusive education seen in light of curriculum potential A content analysis of Norwegian national curricula post 1980. Curriculum J. 2011;22(4):549-66. https://doi.org/10.1080/09585176.2011.627216.

Blackwell WH, Powell M, Dukes GH. The problem of student acceptance of evolution. J Biol Educ. 2003;37(2):58-67.

Boujaoude S, Asghar A, Wiles JR, Jaber L, Sarieddine D, Alters B. Biology professors' and teachers' positions regarding biological evolution and evolution education in a middle eastern society. Int J Sci Educ. 2011;33(7):979-1000.

Burrill G, Lappan G, Gonulates F. Curriculum and the Role of Research. In: Cho $\mathrm{S}$, editor. The Proceedings of the 12th International Congress on Mathematical Education. Springer, Cham 2015.

Bybee R. Evolution in perspective: The science teacher's compendium. Arlington, VA: NSTA Press; 2003.

Campos R, Sá-Pinto A. Early evolution of evolutionary thinking: teaching evolution in elementary schools. Evol Educ Outreach. 2013;6(1):25. https:// doi.org/10.1186/1936-6434-6-25.

Carroll SP, Jørgensen PS, Kinnison MT, Bergstrom CT, Denison RF, Gluckman P, Smith TB, Strauss SY, Tabashnik BE. Applying evolutionary biology to address global challenges. Science. 2014;346(6207):1245993. https:// doi.org/10.1126/science.1245993.

Catley KM, Novick LR. Digging deep: Exploring college students' knowledge of macroevolutionary time. J Res Sci Teach. 2009;46(3):311-32.

Chuang HC. Teaching evolution: Attitudes and strategies of educators in Utah. Am Biol Teacher. 2003;65(9):669-74.

Cotner S, Brooks DC, Moore R. Is the age of the earth one of our "sorest troubles?" students' perceptions about deep time affect their acceptance of evolutionary theory. Evolution. 2010;64(3):858-64. https://doi.org/10.11 11/j.1558-5646.2009.00911.x.

Ehrlinger J, Johnson K, Banner M, Dunning D. Why the unskilled are unaware: further explorations of (absent) self-insight among the incompetent. Organ Behav Hum Decis Process. 2008;105(1):98-121.

Emmons N, Lees K, Kelemen D. Young children's near and far transfer of the basic theory of natural selection: an analogical storybook intervention. J Res Sci Teach. 2017;55(3):321-47. https://doi.org/10.1002/tea.21421.

Erdoğan M, Kostova Z, Marcinkowski T. Components of environmental literacy in elementary science education curriculum in Bulgaria and Turkey. EURASIA J Math Sci Tech Educ. 2009:5(1):15-26.

Eurydice (2019). Slovenia overview, 2019. https://eacea.ec.europa.eu/nationalpolicies/eurydice/content/slovenia_en. Accessed 10/11/2019.

Evans EM. Conceptual change and evolutionary biology: A develop- mental analysis. In: Vosniadou S, editor. International handbook of research on conceptual change. New York: Routledge; 2008. p. 263-94.

Frankel JR., Wallen NE, \& Hyun HH. (2012). How to design and evaluate research in education (8th ed.). McGraw Hill.

Freeman S, Eddy SL, McDonough M, Smith MK, Okoroafor N, Jordt H, Wenderoth MP. Active learning increases student performance in science, engineering, and mathematics. Proc Natl Acad Sci USA. 2014;111:8410-5.

Fowler SR, Zeidler DL. Lack of evolution acceptance inhibits students' negotiation of biology-based socioscientific issues. J Biol Edu. 2016;50(4):40724. https://doi.org/10.1080/00219266.2016.1150869.

Gelman SA. The essential child: Origins of essentialism in everyday thought. New York: Oxford University Press; 2003.

Goldston MJD, Kyzer P. Teaching evolution: Narratives with a view from three southern biology teachers in the USA. J Res Sci Teach. 2000;46(7):762-90.
Gould SJ. The structure of evolutionary theory. Cambridge, MA: Harvard University Press; 2002.

Gov.si. Republic of Slovenia (2020). Programi in učni načrti v osnovni šoli [Programs and syllabuses in compulsory basic school]. Retrieved from https ://www.gov.si/teme/programi-in-ucni-nacrti-v-osnovni-soli/

Government's Gazette Vol. B, No. 304/13-03-03 [in Greek] A $\triangle$ A: 6YXI4653П乏$\mathrm{X} \psi \mathrm{E}$ https://www.alfavita.gr/sites/default/files/attachments/didak tea_ili.pdf. Accessed 10/11/2019.

Graneheim UH, Lundman B. Qualitative content analysis in nursing research: concepts, procedures and measures to achieve trustworthiness. Nurse Educ Today. 2004;24(2):105-12. https://doi.org/10.1016/j. nedt.2003.10.001.

Gresch H, Martens M. Teleology as a tacit dimension of teaching and learning evolution: A sociological approach to classroom interaction in science education. J Res Sci Teach. 2019;56(3):243-69. https://doi.org/10.1002/ tea.21518.

Griffith JA, Brem SK. Teaching evolutionary biology: Pressures, stress, and coping. J Res Sci Teaching. 2004;41(8):791-809.

Hanisch S, Eirdosh, D. Challenges with conceptualizations of evolution in biology education. 2020. https://doi.org/10.13140/RG.2.2.26589.64484. https://www.researchgate.net/publication/342492432

Handelsman J, Ebert-May D, Beichner R, Bruns P, Chang A, DeHaan R, Gentile J, Lauffer S, Stewart J, Tilghman SM, Wood WW. Scientific Teaching. Sci. 2004;304:521-2.

Harlen W. Principles and big ideas of science education. Hatfield: ASE - Association for Science Education College Lane; 2010. https://www.ase.org. uk/bigideas. Accessed 10/11/2019.

Hayes AF, Krippendorff K. Answering the call for a standard reliability measure for coding data. Communication Methods Measures. 2007;1:77-89.

Heddy BC, Nadelson LS. A global perspective of the variables associated with acceptance of evolution. Evol Educ Outreach. 2012;5(3):412-8.

Holbrook J, Rannikmae M. The nature of science education for enhancing scientific literacy. Int J Sci Edu. 2007;29(11):1347-62. https://doi. org/10.1080/09500690601007549.

Hull D. Universal Darwinism. Nature. 1995;377(6549):494. https://doi. org/10.1038/377494a0.

Indicazioni nazionali per il curricolo della scuola dell'infanzia e del primo ciclo d'istruzione (D.M. 254 del 16 novembre 2012): http://www.indicazion inazionali.it/2018/08/26/indicazioni-2012/ Accessed 10/11/2019.

Indicazioni nazionali riguardanti gli obiettivi specifici di apprendimento concernenti le attività e gli insegnamenti compresi nei piani degli studi previsti per i percorsi liceali (D.M. n 211 del 7/10/2010).

Kelemen D. Why are rocks pointy? Children's preference for teleological explanations of the natural world. Dev Psychol. 1999;35(6):1440-52

Kelemen D. Teleological minds: How natural intuitions about agency and purpose influence learning about evolution. In Rosengren KS, Brem SK, Evans EM, \& Sinatra GM. Evolution Challenges: Integrating Research and Practice in Teaching and Learning about Evolution. Oxford University Press; 2012. p.66-92

Kelemen D, Emmons NA, Schillaci RS, Ganea PA. Young Children Can Be Taught Basic Natural Selection Using A Picture Storybook Intervention. Psychol Sci. 2014;25(4):893-902. https://doi.org/10.1177/0956797613516009.

Kelemen D, Rottman J, Seston R. Professional physical scientists display tenacious teleological tendencies: purpose-based reasoning as a cognitive default. J Exp Psychol Gen. 2013;142(4):1074-83.

Krippendorff K. Computing Krippendorff's Alpha-Reliability. 2011; Retrieved from https://repository.upenn.edu/asc_papers/43. Accessed 20/11/2019.

Krippendorff K. Content analysis: An introduction to its methodology. 2nd ed. Thousand Oaks, California: Sage Publications; 2004.

Kruger J, Mueller RA. Unskilled, unaware, or both? The better-than average heuristic and statistical regression predict errors in estimates of own performance. J Pers Soc Psychol. 2002;82(2):180-8.

Kuschmierz P, Beniermann A, Graf D. Development and evaluation of the knowledge about evolution 2.0 instrument (KAEVO 2.0). Int J Sci Educ. 2020:42(15):2601-29. https://doi.org/10.1080/09500693.2020.1822561.

Kyngäs H, Kaakinen P. Deductive Content Analysis. In: Kyngäs H, Mikkonen K, Kääriäinen M, editors. The Application of Content Analysis in Nursing Science Research. Springer, Cham; 2020. p. 23-30. https://doi. org/10.1007/978-3-030-30199-6_3 
Labov JB, Singer SR, George MD, Schweingruber HA, Hilton ML. Effective practices in undergraduate STEM education: part 1. Examining the evidence. CBE Life Sci Educ. 2009:8:157-61.

Lederberg J. Pandemic as a Natural Evolutionary Phenomenon. Soc Res. 1988;55(3):342-57.

Lederman NG. Contextualizing the relationship between nature of scientific knowledge and scientific inquiry implications for curriculum and classroom practice. Sci Educ. 2019;28:249-67.

Lombrozo T, Thanukos A, Weisberg M. The importance of understanding the nature of science for accepting evolution. Evol Educ Outreach. 2008:1:290-8.

Miller JD, Scott EC, Okamoto S. Public Acceptance of Evolution. Science. 2006;313(5788):765-6. https://doi.org/10.1126/science.1126746.

Mkumbo KA. Content analysis of the status and place of sexuality education in the national school policy and curriculum in Tanzania. Educ Res Rev. 2009;4(12):616-25.

National Academy of Sciences. Teaching About Evolution and the Nature of Science. Washington, DC: The National Academies Press. 1998. https:// doi.org/10.17226/5787.

National Academy of Sciences. Science and creationism: A view from the National Academy of Sciences. 2nd ed. Washington, DC: National Academy Press; 1999

National Research Council. 2007. Taking Science to School: Learning and Teaching Science in Grades K-8. Committee on Science Learning, Kindergarten Through Eighth Grade. In Duschl RA, Schweingruber HA, and Shouse AW, editors. Board on Science Education, Center for Education. Division of Behavioral and Social Sciences and Education. Washington, DC: The National Academies Press; 2007.

National Research Council. A Framework for K-12 Science Education: Practices, Crosscutting Concepts, and Core Ideas. Committee on a Conceptual Framework for New K-12 Science Education Standards. Board on Science Education, Division of Behavioral and Social Sciences and Education. Washington, DC: The National Academies Press; 2012.

National Research Council. 2013. Next Generation Science Standards: For States, By States. Washington, DC: The National Academies Press. https ://doi.org/10.17226/18290.

Nehm R, Reilly L. Biology Majors' knowledge and misconceptions of natural selection. Bioscience. 2007:57(3):263-72.

Nehm RH, Kim SY, Sheppard K. Academic preparation in biology and advocacy for teaching evolution: Biology versus non-biology teachers. Sci Educ. 2009a;93(6):1122-46.

Nehm R, Poole T, Lyford M, Hoskins S, Carruth L, Ewers B, Colberg P. Does the segregation of evolution in biology textbooks and introductory courses reinforce students' mental models of biology and evolution? Evo Edu Outreach. 2009b;2(3):527-32.

Nelson CE, Scharmann LC, Beard J, Flammer LI. The nature of science as a foundation for fostering a better understanding of evolution. Evo Edu Outreach. 2019;12(1):6. https://doi.org/10.1186/s12052-019-0100-7.

Peel A, Zangori L, Friedrichsen P, Hayes E, Sadler TD. Students' model-based explanations about natural selection and antibiotic resistance through socio-scientific issues-based learning. Int J Sci Edu. 2019:41(4):510-32.

Pinxten $R$, Vandervieren $E$, Janssenswillen P. Does integrating natural selection throughout upper secondary biology education result in a better understanding: a cross-national comparison between flanders, Belgium and the Netherlands. Int J Sci Educ. 2020;42(10):1609-34. https://doi. org/10.1080/09500693.2020.1773005.

Plutzer, E, Branch, G, Reid, A. Teaching evolution in US public schools: A continuing challenge. Evolution: Education and Outreach. 2020. https://doi. org/10.1186/s12052-020-00126-8

Portuguese Assembly of Republic (2009). Law n. 85/2009, from 27 of August. https://dre.pt/application/conteudo/488826 Accessed 05/10/2019.

Portuguese Government/Decree-Law n. 0 55/2018, from 6 july. https://dre.pt/ application/conteudo/115652962. Accessed 05/10/2019.

Portuguese Government/Ministry of Education. Essential learning goals. 1st grade: Basic Education. 1st Cycle. Study of the Environment. 2018a https://www.dge.mec.pt/sites/default/files/Curriculo/Aprendizag ens_Essenciais/1_ciclo/1_estudo_do_meio.pdf

Portuguese Government/Ministry of Education. Essential learning goals. Basic Education. 2nd grade:1st Cycle. Study of the Environment. 2018b https ://www.dge.mec.pt/sites/default/files/Curriculo/Aprendizagens_Essen ciais/1_ciclo/2_estudo_do_meio.pdf
Portuguese Government/Ministry of Education. Essential learning goals. 3rd grade: Basic Education. 1st Cycle. Study of the Environment.2018c https ://www.dge.mec.pt/sites/default/files/Curriculo/Aprendizagens_Essen ciais/1_ciclo/3_estudo_do_meio.pdf

Portuguese Government/Ministry of Education. Essential learning goals. 4th grade: Basic Education. 1st Cycle. Study of the Environment. 2018d https://www.dge.mec.pt/sites/default/files/Curriculo/Aprendizag ens_Essenciais/1_ciclo/4_estudo_do_meio.pdf

Portuguese Government/Ministry of Education. Essential learning goals. 5th grade: Basic Education. 2nd Cycle. Natural Sciences. 2018e https:// www.dge.mec.pt/sites/default/files/Curriculo/Aprendizagens_Essen ciais/2_ciclo/5_ciencias_naturais.pdf

Portuguese Government/Ministry of Education. Essential learning goals. 6th grade: Basic Education. 2nd Cycle. Natural Sciences. 2018f https://www. dge.mec.pt/sites/default/files/Curriculo/Aprendizagens_Essenciais /2_ciclo/6_ciencias_naturais.pdf

Portuguese Government/Ministry of Education. Essential learning goals. 7th grade: Basic Education. 3rd Cycle. Natural Sciences. 2018g https://www. dge.mec.pt/sites/default/files/Curriculo/Aprendizagens_Essenciais /3_ciclo/ciencias_naturais_3c_7a_ff.pdf

Portuguese Government/Ministry of Education. Essential learning goals. 8th grade: Basic Education. 3rd Cycle. Natural Sciences. 2018h https://www. dge.mec.pt/sites/default/files/Curriculo/Aprendizagens_Essenciais /3_ciclo/ciencias_naturais_3c_8a_ff.pdf

Portuguese Government/Ministry of Education. Essential learning goals. 9th grade: Basic Education. 3rd Cycle. Natural Sciences; 2018i https://www. dge.mec.pt/sites/default/files/Curriculo/Aprendizagens_Essenciais /3_ciclo/ciencias_naturais_3c_9a_ff.pdf

Potter WJ, Levine-Donnerstein D. Rethinking validity and reliability in content analysis. J App Comm Res. 1999;27(3):258-84. https://doi. org/10.1080/00909889909365539.

Price RM, Andrews TC, Mcelhinny TL, Mead LS, Abraham JK, Thanukos A, Perez $K E$. The genetic drift inventory: a tool for measuring what advanced undergraduates have mastered about genetic drift. Cell Biol Educ. 2014;13(1):65-75. https://doi.org/10.1187/cbe.13-08-0159.

Prideaux D. ABC of learning and teaching in medicine: Curriculum design. BMJ. 2003;326(7383):268-70. https://doi.org/10.1136/bmj.326.7383.26.

Prinou L, Halkia L, Skordoulis C. What Conceptions do Greek School Students Form about Biological Evolution? Evo Edu Outreach. 2008;1 (3):312-7. https://doi.org/10.1007/s12052-008-0051-x.

Prinou L, Halkia L, Skordoulis C. The Inability of Primary School to Introduce Children to the Theory of Biological Evolution. Evo Edu Outreach. 2011;4(2):275-85. https://doi.org/10.1007/s12052-011-0323-8.

Quessada MP, Clément P. The origin of humankind: a survey of school textbooks and teachers' conceptions in 14 countries. In: Yarden A and Carvalho GS, editors. Authenticity in Biology Education. Benefits and Challenges. Braga (Portugal): ERIDOB \& CIEC, Minho University; 2011. p.295-307.

Rector MA, Nehm RH, Pearl D. Learning the language of evolution: Lexical ambiguity and word meaning in student explanations. Res Sci Educ. 2013:43(3):1107-33. https://doi.org/10.1007/s11165-012-9296-z.

Regolamento recante norme concernenti il riordino degli istituti tecnici ai sensi dell'articolo 64, comma 4, del decreto legge 25 giugno 2008, n. 112, convertito dalla legge 6 agosto 2008, n. 133;

Regolamento recante norme concernenti il riordino degli istituti professionali ai sensi dell'articolo 64, comma 4, del decreto legge 25 giugno 2008, n. 112, convertito dalla legge 6 agosto 2008, n. 133: http://archivio.pubbl ica.istruzione.it/riforma_superiori/nuovesuperiori/index.html

Rottman J, Zhu L, Wang W, Schillaci RS, Clark KJ, Kelemen D. Cultural influences on the teleological stance: evidence from China. Religion Brain Behavior. 2017;7(1):17-26

Rudolph J, Stewart J. Evolution and the Nature of Science: On the Historical Discord and Its Implications for Education. J Res Sci Teach. 1998:35:1069-89.

Sá-Pinto X, Cardia P, Campos R. Sexual selection: a short review on its causes and outcomes and activities to teach evolution and the nature of science. Amer Biol Teach. 2017;79(2):135-43. https://doi.org/10.1525/ abt.2017.79.2.135.

Sadler TD. Evolutionary theory as a guide to socioscientific decision-making. J Biol Edu. 2005:39(2):68-72. 
Sanders M, Makotsa D. The possible influence of curriculum statements and textbooks on misconceptions: The case of evolution. Educ as Change. 2016;20(1):1-23. https://doi.org/10.1719/1947-9417/2015/555.

Scharmann LC. Evolution and nature of science instruction. Evol Educ Outreach. 2018;11:14.

Scheuch M, Rachbauer S. Teaching evolution with Austrian biology textbooks. In: New perspectives in science education (Vol. 8, 4p). Firenze (Italy): libreriauniversitaria.it; 2019. https://doi.org/10.26352/D321_2420-9732

Scholl D. Are the traditional curricula dispensable? a feature pattern to compare different types of curriculum and a critical view of educational standards and essential curricula in Germany. Europ Educ Res J. 2012;11(3):328-41. https://doi.org/10.2304/eerj.2012.11.3.328.

Scotchmoor J, Thanukos A. Building an understanding of evolution: an online resource for teaching and learning. McGill J Educ. 2007;42(2):225-44

Seker H, Guney BG. History of science in the physics curriculum: a directed content analysis of historical sources. Sci Educ. 2012;2:683-703. https:// doi.org/10.1007/s11191-011-9416-6.

Shtulman A. Qualitative differences between naive and scientific theories of evolution. Cogn Psychol. 2006;52:170-94.

Sieckel AJ, Friedrichsen P. Examining the evolution education literature with a focus on teachers: major findings, goals for teacher preparation, and directions for future research. Evo Edu Outreach. 2013;6(23):1-15.

Sinatra G, Brem S, Evans EM. Changing minds? Implications of conceptual change for teaching and learning about biological evolution. Evo Edu Outreach. 2008;1 (2):189-95.

Singer S, Nielsen N, Schweingruber H. Discipline-based education research: understanding and improving learning in undergraduate science and engineering. Washington, D.C: National Academies Press; 2012.

Skoog G, Bilica K. The emphasis given to evolution in state standards: a lever for change in evolution? Sci Educ. 2002;86:445-62.

Tibell LAE, Harms U. Biological principles and threshold concepts for understanding natural selection Implications for the developing and visualization as a pedagogic tool. Sci Educ. 2017;26:953-73.

Tidon R, Lewontin RC. Teaching evolutionary biology. Gen Mol Biol. 2004;27(1):124-31. https://doi.org/10.1590/S1415-47572004000100021.

Udir. Natural Science subject curriculum (NAT1-03); 2013. https://www.udir. no/kl06/NAT1-03/Hele/Komplett_visning/?lplang=eng\&read=1. Acessed 27 February 2020.

Udir. Naturfag (NAT01-04) Kompetansemål og vurdering; 2020 https://www. udir.no/k20/nat01-04/kompetansemaal-og-vurdering/kv78. Accessed 27 February 2020.

Understanding Evolution. 2020. University of California Museum of Paleontology. Accessed 07 July 2020 http://evolution.berkeley.edu/.

Van Dijk EM, Reydon TAC. A conceptual analysis of evolutionary theory for teacher education. Sci Educ. 2010;19:6-7.

Vaughn AR, Robbins JR. Preparing Preservice K-8 Teachers for the Public School: Improving Evolution Attitudes, Misconceptions, and Legal Confusion. J College Sci Teach. 2017:47(2):7-15.

Venetis K, Mavrikaki E. Oi gnoseis ton ekpaideytikon thetikon epistimon shetika me tous exeliktikous mixanismous ton zontanon organismon. Sto A. Polyzos, L. Anthis (epim.), Praktika Ergasion 4th Panelliniou Synedriou "Biologia stin Ekpaideusi" [Knowledge of secondary education science teachers regarding the evolutionary mechanisms of living organisms. In: Polyzos A, Anthis L, editors. Proceedings of the 4th Panhellenic Conference "Biology in Education"]. Piraeus: Panhellenic Association of Bioscientists; 2017. p. 143-151.

Wieman CE. Large-scale comparison of science teaching methods sends clear message. Proc Natl Acad Sci USA. 2014;111:8319-20.

Wyner Y, Desalle R. Distinguishing Extinction and Natural Selection in the Anthropocene: Preventing the Panda Paradox through Practical Education Measures. BioEssays. 2020;42(2):1900206

Yasri P, Mancy R. Student positions on the relationship between evolution and creation: what kinds of changes occur and for what reasons? J Res Sci Teaching. 2016;53(3):384-99.

Yates TB, Marek EA. Teachers teaching misconceptions: a study of factors contributing to high school biology students' acquisition of biological evolution-related misconceptions. Evol Edu Outreach. 2014;7(1):7.

Young M. What is a curriculum and what can it do? Curriculum J. 2014;25(1):713. https://doi.org/10.1080/09585176.2014.902526.

\section{Publisher's Note}

Springer Nature remains neutral with regard to jurisdictional claims in published maps and institutional affiliations.
Ready to submit your research? Choose BMC and benefit from:

- fast, convenient online submission

- thorough peer review by experienced researchers in your field

- rapid publication on acceptance

- support for research data, including large and complex data types

- gold Open Access which fosters wider collaboration and increased citations

- maximum visibility for your research: over $100 \mathrm{M}$ website views per year

At BMC, research is always in progress.

Learn more biomedcentral.com/submissions 